\title{
Darbelere Giden Süreçte Kamusal Rıza Üretiminde Basının Rolü: 27 Mayıs 1960 ve 15 Temmuz 2016'nın Karşılaştırmalı Analizi $^{*}$
}

\author{
Role of Press in the Production of Public Consent for Military Coups in Turkey: \\ Comparative Analysis of 27 May 1960 and 15 July 2016
}

\section{Serpil Seda ŞíMŞEK ${ }^{*}$}

Öz

Türk siyasi hayatındaki darbelerin hazırlanış safhasında, gerçekleştirilmesinde ve sonrasında meşrulaştırılmasında asker, yargı, akademinin yanı sıra en önemli aktörlerden birisini de medya oluşturmaktadır.27 Mayıs 1960 Türkiye Cumhuriyeti siyasi tarihindeki ilk darbe, 15 Temmuz 2016 ise günümüze kadar gerçekleşmiş son Darbe Girişimi özelliği taşımaktadır. Bu çalışmada, 27 Mayıs Darbesi ve 15 Temmuz Darbe Girişimi öncesinde, basında, özellikle "diktatörlük”, “otoriterlik”, "yolsuzluk”, "fikir ve ifade hürriyetine baskı” kavramları etrafında oluşan darbeye kamusal rıza üretimi süreci ele alınmıştır. İlk olarak Antonio Gramsci’nin "hegemonya” ve Louis Althusser’in "devletin ideolojik aygıtları”na ilişkin teorileri kapsamında, medyanın darbe süreçlerindeki tutumu ile Türkiye’deki hegemonya arasındaki ilişki açıklanmaya çalışılmıştır. Ardından da bu iki örnek olayda kamusal rızanın nasıl üretildiği, "Kamusal Senaryo Modeli”, Herbert Schiller ve Noam Chomsky'nin medya manipülasyonu analizleri çerçevesinde incelenmiştir. Merkez medya ve uluslararası medyanın bilerek veya bilmeyerek 15 Temmuz’a giden süreçte, 27 Mayıs darbesi öncesine benzer şekilde sivil ve demokratik yönetime karşı bir askeri darbeye rıza üretimi sürecinin parçası olduğu tespit edilmiştir.

Anahtar Kelimeler: 15 Temmuz, 27 Mayıs, medya, Recep Tayyip Erdoğan, Adnan Menderes.

\section{Abstract}

The media is one of the most important actors of the preparation, execution and justification of military coups in Turkey along with the judiciary and the academy. 27 May 1960 military coup is the first military

* Atılım Üniversitesi Sosyal Bilimler Enstitüsü Kamu Yönetimi ve Siyaset Bilimi Ana Bilim Dalı bünyesinde hazırlanan ve savunma tarihi Haziran 2018 olan yüksek lisans tezinden üretilmiştir.

** Doktora öğrencisi, Kocaeli Üniversitesi Sosyal Bilimler Enstitüsü, Siyaset Bilimi ve Kamu Yönetimi Ana Bilim Dalı, Kocaeli, Türkiye, ssedasimsek@gmail.com, Orcid ID: 0000-0001-8016-5566 
coup in the history of the Turkish Republic, while the July 15th, 2016 failed coup attempt is the last. In this study, the process of generating public consent for both coups in the media are examined especially through the "dictatorship", "authoritarianism", "corruption", "suppression of freedom of thought and speech" concepts. Utilizing the theoretical frameworks of Antonio Gramsci's "hegemony" and Louis Althusser's "ideological state apparatuses", the article first discusses the relationship between the media's attitude in the process leading to military coups and hegemony in Turkey. Then, it analyzes how public consent is generated by utilizing "public scenario model" and Herbert Schiller's and Noam Chomsky's insights on media manipulation. The study argues that the mainstream media, knowingly or unknowingly, has been part of the process of manufacturing public consent for the military coup against the civilian and democratic government before the July 15, 2016 failed coup, similar to the process leading up to the May 27, 1960 coup d'etat.

Keywords: The July 15th, the May 27th, media, Recep Tayyip Erdogan, Adnan Menderes.

\section{Giriş}

27 Mayıs'ı, darbeyi gerçekleştirenler veya darbeyi destekleyenler genellikle "devrim", "ihtilâl", "müdahale" gibi kelimelerle kavramsallaştırmaya çalışırken, darbeye maruz kalanlar ve özellikle Demokrat Partisi (DP) mensupları "darbe", "hükümet darbesi" olarak ifade etmektedir. 15 Temmuz ise, bu çalışma yapıldığı dönemde "Darbe Girişimi”" ifadesiyle nitelendirilmektedir. 27 Mayıs 1960 Darbesi, Türkiye Cumhuriyeti siyasi tarihinin ilk askeri darbesi olması sebebiyle Türkiyede daha sonra yaşanan askeri müdahalelerin ve askeri darbelerin ilham kaynağı olmuştur. Türk siyasi hayatındaki darbelerin hazırlanış safhasında, gerçekleştirilmesinde ve sonrasında meşrulaştırılmasında asker, yargı, akademinin yanı sıra en önemli aktörlerden birisini de medya oluşturmaktadır. Toplumun darbeye hazırlanması ve darbenin gerçekleşmesinin ardından da meşruiyetinin sağlanmasında kitle iletişim araçlarının etkisi olduğu açıktır. Kitle iletişim araçlarından iletilen mesajlarla toplum yönlendirilebilmekte, hatta manipüle edilebilmektedir.

$\mathrm{Bu}$ araştırmada, 27 Mayıs Darbesi’ne ve 15 Temmuz Darbe Girişimi’ne giden süreçte gazete yayınlarının, darbeye rıza üretiminde nasıl bir rol oynadığı irdelenmiştir. Noam Chomsky ve Edward S. Herman’nın (2012) rıza üretiminde egemen ideolojinin korunması ve yeniden kurulması görevini üstlenen bir güç olarak tanımladığı, Antonio Gramsci’nin (1967) hegemonyanın kurulmasında en önemli vasitalardan biri olarak ifade ettiği, Louis Althusser'in (2017) devletin ideolojik aygitları arasında saydığ 1 basın, kamuoyunu etkileme kapasitesi ile daima tartışmaların ana gündeminde yer almıştır. Gerek Gramsci'ye gerek Althussere göre egemen sınıflar, manevi, maddi, etnik, dini, kültürel, ideolojik, siyasi, ekonomik alandaki güçleri ile daima toplumu manipüle edebilmekte veya belli baskı unsurlarını kullanarak kendi söylem ve anlayışlarını tüm toplum üzerinde aşamalı olarak kabul ettirebilmektedir (Miller, Coleman, Connolly ve Ryan, 1994, s. 304). Bu bağlamda, Gramsci ve Althusser'in teorik analizlerine, Türkiyedeki hegemonyanın ve darbe süreçlerinde medyanın tutumunun tahlilinde başvurulmuştur.

$\mathrm{Bu}$ çalışmada, darbe süreçlerinde gazetelerden seçilen haber ve olay örnekleriyle, toplumsal rızanın üretilmesine ve korunmasına ilişkin kullanılan söylem yapıları açılanmaya çalışılmıştır. Gazete haberlerinin taranması sebebiyle "tarama" yöntemine, ayrıca "çerçeveleme" ve "ideolojik 
kare" yöntemlerine başvurulmuştur. Araştırma, 27 Mayıs Darbesi için 1958-1960 arasında Türkiye’de yayın yapan dönemin gazetelerinden DP’ye muhalif Vatan (Kuruluşunda DP yanlısı olmakla birlikte özellikle 1957'den sonra DP'ye muhaliftir), Cumhuriyet Halk Partisine (CHP) yakın yayın çizgisi izleyen Ulus ve Cumhuriyet, ikisine nazaran daha merkezde yer alan Milliyet ve Akşam gazeteleriyle Yüksek Haysiyet Divanı’nın Gerekçeli Kararı’nda idam kararlarına delil gösterilen haberlerin yer aldığı uluslararası basınla sınırlandırılmıştır. 15 Temmuz Darbe Girişimi’ne giden süreçte ise, 20132016 arasında Adalet ve Kalkınma Partisine (AK Parti) muhalif bir yayın çizgisi izleyen Cumhuriyet ile merkez medya olarak adlandırılan Hürriyet ve Milliyet gazeteleriyle sınırlandırılmış, uluslararası medyadan The Washington Post, The New York Times, The Times, Time, The Independent gazeteleri taranmıştır. Haber sayfalarında konuya ilişkin yayınlanan haberler tarama metodu yoluyla taranarak 27 Mayıs Darbesi ve 15 Temmuz Darbe Girişimi öncesinde yapılan haberlerde "diktatör", "yolsuzluk", "otoriterleşme", "fikir ve ifade hürriyetine baskı" konulu haberler ve köşe yazıları derlenmiştir. Araştırma, "Kemalist hegemonya"nın ideolojisini benimsediği genel kabul gören yayın organlarıyla sinırlandırılmıştır.

Hem 27 Mayıs 1960 darbesi hem de 15 Temmuz 2016 Darbe Girişiminde basının rolü veya işlevi, Gramsci'nin "hegemonya", Althusser'in "devletin ideolojik aygıtları" teorileri ve onların kuramlarını esas alan eleştirel medya yaklaşımıyla Mehmet Sezai Türk ve Zülfikar Damlapınar’ın "Kamusal Senaryo Modeli" ve Herbert Schiller ve Noam Chomsky'nin medya manipülasyonu analizleri çerçevesinde incelenerek literatüre katkı sunulmaya çalışılmıştır. Çalışmada, 27 Mayıs 1960 darbesi ve 15 Temmuz 2016 Darbe Girişimi öncesinde, "diktatörlük", "otoriterleşme", "fikir ve ifade hürriyetine baskı" ve "muhalefete baskı" söylemlerinin birbiriyle benzer cümlelerle, ifadelerle, fotoğraflarla içeriklendirilerek sistemli olarak tekrar edilmesiyle medyanın darbe süreçlerinde rıza üretimindeki işlevi ortaya konulmaktadır. Böylelikle, hegemonyanın ideolojisini benimseyen ve devletin ideolojik aygıtı olan kitle iletişim araçlarının söylemleriyle darbeye rıza üretimi çabası içinde oldukları bulgusuna ulaşılmaktadır.

\section{Hegemonya ve Devlet Aygıtı Perspektifinden Türkiye'de Medyanın İşlevi}

Antonio Gramsci'ye (2014) göre, bir sosyal grup, sınıf veya devlet, egemenliği kısmen baskıyla ve daha çok da çoğunluğun rızasına dayanarak sağlar. Gramsci, bir grubun iktidarı ele geçirmeden yönetici olabileceğini de ileri sürmektedir (s. 33). Başka bir ifadeyle hegemonya, bir sınıfın egemen olmasından ziyade yönetmesiyle işlemektedir. Hegemonya kavramsallaştırmasında, doğrudan silaha ve zora başvurulması yerine, ideolojinin ve buna bağlı olarak manipülasyonun vasıtaları tercih edilmektedir. Hegemonya aracıllğıyla yöneten konumundaki sınıf, yönetilen konumundaki sınıfı, yöneten sınıfın isteği doğrultusunda yönlendirip manipüle edebilmektedir (Thomas, 2013, s. 11). Hegemonya, rıza üretiminde ideolojik araçlara başvurmaktadır (Fairclough, 2015, s. 127). Bundan dolayı da rızanın üretiminde, aydınlara ihtiyaç duyulur. Aydınlar aracıllğıyla toplumsal rıza üretilmekte ve yönlendirilmektedir (Demirovic, 2012, s. 98). Aydınların rıza üretiminde kullandıkları önemli aygıtlardan birisi de kitle iletişim araçlarıdır. Hegemonya, üstyapı kurumları (aile, öğretim sistemi, kilise, kitle iletişim araçları ve kültürel örgütler) aracılığıyla ve devletin baskıcı yanıyla (silahlı kuvvetler, polis, yasalar) çalışmaktadır; dondurulmuş bir yapı değil, dinamik, kazanılması ve 
korunması gereken bir yapıyı (Erdoğan ve Alemdar, 2010, s. 268-269) ifade etmektedir. Riza sonucu üretilen hegemonya toplumsal bilince içkin konumdadır, bundan dolayı her seferinde kendini tekrar tekrar kabul ettirmesi ve yenilemesi gerekmemektedir (Russell, 1990, s. 38).

Egemen sinıflar toplumu doğrudan, güç ve tehdit kullanarak yönetmemekte, bunun yerine kendi görüşlerini alt sinıflara kabul ettiren bir strateji izlemektedir (Burke, 2008, s. 35). Gramsci’ye (2014) göre, ideolojiyi temel alan egemen sınıfın hegemonyası, zamanla nihayete ermemektedir. Egemen sınıf, hegemonyasını, politik, ahlaki, kültürel önderliği ile birlikte, biraz da zor kullanarak devam ettirmektedir. Gramsci, hegemonyayı, bir yönetici gücün kendi hâkimiyeti için hükmettiği insanların rızasını alma biçimi anlamında kullandığı gibi bazen de hem rıza hem de baskı anlamını birlikte karşılayacak şekilde kullanmaktadır (s. 341-342). Ona göre, ideoloji ile hegemonya birbirinden farklıdır, hegemonya ideolojiden daha geniş bir kapsama sahiptir. Hegemonya ideolojiyi kapsar, ama ona indirgenemez (Gramsci, 2014, s. 87-89). Egemen sistemdeki baskın öge iktidar olarak kabul edilmektedir, ancak iktidar hegemonyayla kuşatılmış bir baskı aracıdır (Demirovic, 2007, s. 125). Hegemonya, bir sınıfın kendi isteklerini gerçekleştirmek amacıyla oluşturduğu bir riza üretim mekanizmasıdır, bu mekanizma çeşitli alanlarda işlemektedir. Medya, kültür, bilim, sanat, moda, eğlence gibi alanlarda, hegemonyanın alametleri görülebilir.

Biçimsel örgütleniş açısından demokratik olan, ama aynı zamanda ekonomik sermayenin ve siyasal iktidarın farklılaşmasıyla, zenginlik ve otoritenin dengesiz dağılımının üstünü örtebilecek en önemli öge rıza üretimidir (Hall, 1994, s. 67). Yani, Gramsci'nin hegemonya anlayışının temelini "rıza" oluşturmaktadır. Gramsci'ye göre rıza üretilen bir şeydir ve hegemonya da rızanın üretilmesidir (Akt. Marshall, 1999, s. 300). Basın gibi destekleyici aparatlar kullanarak, hegemonya doğal ve alışlmış hâle getirilirken rıza da üretilir (Ceylan, 2013, s. 332). Medya bu işlevi görürken, zaman zaman milli egemenliğe ortak olabilmekte ve bir toplumda siyasi yapının bir gücü haline gelebilmektedir ve bu gücü kullanırken herhangi bir sorumluluk da üstlenmemektedir (Zorlu, 2016, s. 855; Keane, 1999, s. 136).

Medya hakkında kuramsal değerlendirmeler genellikle iki yaklaşım üzerinden yapılmaktadır. Bunlar, liberal dünya görüşünden kaynaklanan, çoğulcu toplum idealini kapsayan kuramlara atıfta bulunan "ana akım" ya da "liberal-çoğulcu yaklaşım" ve sınıflı toplumlarda çıkarların farklı olduğu, bunların çatıştığı ve hâkim konumdaki sınıfın hegemonyasının belirleyici olduğu ana akım yaklaşımın eleştirisine dayanan "eleştirel yaklaşımlar"dır (Kaya ve Çakmur, 2012, s. 518-519). Her iki yaklaşımda da medyanın konumu farklıdır. Liberal yaklaşım veya ana akım yaklaşımda, medya incelemeleri evrimci bir bakış açısı içermektedir. Buna göre, sistemin özüne dokunulmaz, sistemin parçalarındaki değişim zamana bırakılır. Eleştirel yaklaşımlarda ise medya incelemeleri, daha çok incelenen konunun ve toplumun, sistemin dönüştürülebileceği düşüncesini esas alır (Yaylagül, 2010, s. 22). Liberal yaklaşım, kitle iletişim araçlarının ifade özgürlüğünün korunmasında vazgeçilmez olduğu ön kabulünden hareket ederken, Marksist bakış açısında, kitle iletişim araçlarının, statükonun toplumsal yeniden üretiminde rol aldığı kabul edilir. Marksizm, kitle iletişim araçlarına, eşitsiz toplumsal ilişkilerin, ideolojik toplum imgelerinin şekillenmesinde destek rolü vermektedir (Stevenson, 2008, s. 25). 
Liberal sistemde medya, kamu gözcüsü, halkın temsilcisi ve bilgi verici olarak sunulmakta ve basin özgürlüğü düşüncesi, kamusal iletişim alanının devletin denetim ve müdahalesinden kurtarılmasını kapsamaktadır (Uzun, 2011, s. 36). Kitle iletişim araçlarına verilen gözetleme rolü, demokratik bir işlev olarak görülmektedir (Curran, 2002, s. 186). Medyadan, toplumda birlikteliği güçlendirmesi, düzeni koruması, değişimin ve gelişimin istikrar içerisinde gerçekleşmesine hizmet etmesi beklenir (Kaya ve Çakmur, 2012, s. 520). Liberal yaklaşımda, medyayı, yasama, yürütme ve yargı erklerinin arkasında dördüncü güç yapanın bu özellikleri olduğu söylenebilir. Yaklaşıma göre, medya hakkında bütün bu varsayımların hayata geçmesinin ön koşulu ise, toplumun demokratik temsili bir rejimle yönetilmesi gerekliliğidir (Kaya ve Çakmur, 2012, s. 520).

Eleştirel yaklaşımlar ise tarihsel maddeci kuramın dayandığı, uzlaşmaz (antagonist) sınıflardan oluşan bir toplum tahlilinden hareket etmektedir. Düşünceyi üreten kitle iletişim araçlarının mülkiyeti ve denetimi egemen sınıfa aittir. Dolayısıyla medya, toplumun genel çıkarlarını içeren değil, egemen sınıfın çıkarlarını esas alacak üretim yapmaktadır. Marksist teoriye dayanan bu yaklaşım, kaynağını Gramsci'nin hegemonya ve Althusser'in ideoloji üzerine çalışmalarından almakta, ayrıca Frankfurt Okulu'nun eleştirel düşüncesinden yola çıkmaktadır. Marksist teoride, politik iktidarın, toplumu meşruiyetine ikna etmesinde basın önemli bir araç olarak kabul edilmektedir. Politik iktidarı elinde bulunduranlarla medya sahipleri arasında karşılıklı ilişki, etkileşim ve hatta bağımlılık bulunduğu görüşü savunulmaktadır. $\mathrm{Bu}$ anlayışa göre, medya içeriklerini üretenler, medya kuruluşunun sahibinden özerk ve siyasal iktidardan bağımsız olarak mesleki etkinliklerini sürdüremez (Kaya ve Çakmur, 2012, s. 521).

Portelli (1982), Gramsci’nin toplumun ideolojik yönetiminde, sivil toplumun, "gerçek anlamıyla ideoloji, 'ideolojik yapi', yani ideolojiyi yaratan ve yayan örgütler ve ideolojik 'gereç', yani, okul sistemi, medya, kitaplıklar gibi teknik ideoloji yayma araçları” ile hegemonyaya eklemlendiğine işaret etmektedir (s. 9-15). Marksist temelli yaklaşımlarda, Gramsci'nin hegemonya anlayışının yanı sıra Althusser'in medya-devlet ilişkisi hakkındaki görüşleri de esas alınmaktadır. Althusser devlet mekanizmasının, egemenliğini kurmak ve sürdürmek üzere baskı ve ideolojik aygıtları kullanmasını açılkamaktadır. Althusser’e (2017) göre, "devlet iktidarı (ve onun filancanın elinde olması...)" ile "devlet aygitı"nı birbirinden ayırmak gerekmektedir. Devlet aygit1, hem baskıcı devlet aygitını (hükümet, idare, ordu, polis, mahkemeler, hapishaneler, vb.) temsil eden kurumlar bütününü hem de devletin ideolojik aygitlarından (din, okul, aile, hukuk, partiler, sendikalar, basın ve radyo-televizyon, kültür) meydana gelen kurumlar bütününü kapsamaktadır. Devlet aygıtı, öncelikle fiziksel baskı dâhil baskıya ağırlık vererek, ikinci olarak da ideoloji kullanarak işlemektedir. Bütünüyle baskıya dayalı bir aygıt bulunmamaktadır. Devletin ideolojik aygıtları ise, öncelikle ideolojiye ağırlık vererek, ikincil anlamda ise baskı kullanarak işlemektedir. Bu baskı uç durumlarda, çok hafifletilmiş, gizlenmiş, hatta sembolik olsa bile salt ideolojik bir aygıtta bulunmamaktadır. Devletin ideolojik aygıtlarının hareketi ile (baskıcı) devlet aygıtının arasında durmaksızın açık ya da örtük ince ilişkiler örülmektedir (s. 52-55).

Althusser (2017) medyaya (basın) devletin ideolojik aygitları arasında yer vermektedir. Devletin ideolojik aygıtlarından siyasal aygıt, insanları "dolaylı (parlamenter) ya da dolaysız (plebisitçi ve faşist) demokratik ideoloji” olarak tanımlanabilecek devletin siyasal ideolojisine uydurmaktadır. Dinsel 
aygıt, insana, "ölüm, nikâh, doğum gibi önemli törenler ya da vaazlarla, bir yanağını tokatlayana ötekini sunacak kadar kardeşlerini sevemiyorsa, külden başka bir şey olmadığını” hatırlatmaktadır. Haberleşme aygıtı ise, basın, radyo, televizyon yoluyla, "tüm yurttaşları günlük milliyetçilik, şovenizm, liberalizm, ahlakçılık, vb. dozlarıyla” beslemektedir (s. 57-61).

Yani gerek Gramsci'ye gerek Althusser'e göre, toplumda egemen sinıflar, manevi, maddi, etnik, dini, kültürel, ideolojik, siyasi, ekonomik alandaki güçleri ile daima toplumu manipüle edebilmekte veya belli baskı unsurlarını kullanarak kendi söylem ve anlayışlarını tüm toplum üzerinde aşamalı olarak kabul ettirebilmektedir (Miller, Coleman, Connolly ve Ryan, 1994, s. 304). Bu bağlamda, Gramsci ve Althusser'in teorik analizleri, yine onların kuramlarını temel alan eleştirel medya yaklaşımı, Türkiyedeki hegemonyanın ve darbe süreçlerinde medyanın tutumunun açıklanmasında başvurulabilecek bir teorik çerçeve oluşturmaktadır.

Cumhuriyet modernleş(tir)mesinin katı bir laisizm ve etnik temelli bir milliyetçilik anlayışını içeren ve cumhuriyetin kuruluş felsefesi olarak da tanımlanabilecek "devlet ideolojisi”ne dayanan hegemonya, gerek DP’nin iktidara geldiği 14 Mayıs 1950'den sonra, gerekse 2002 yılında AK Parti’nin iktidara gelmesinin ardından varlığını devam ettirmektedir. Bu noktada, siyasal iktidar ve hegemonya arasındaki farka Türkiye önemli bir örnek teşkil etmektedir. Althusser’e (2017) göre, "devlet iktidarı (ve onun filancanın elinde olması...)" ile "devlet aygıtı"nı birbirinden ayırmak gerekmektedir. Devlet aygıtı, hem baskıcı devlet aygıtını (hükümet, idare, ordu, polis, mahkemeler, hapishaneler, vb.) temsil eden kurumlar bütününü hem de devletin ideolojik aygıtlar (din, okul, aile, hukuk, partiler, sendikalar, basın ve radyo-televizyon, kültür) bütününü temsil eden kurumların tamamını kapsamaktadır (s. 55). Darbeye zemin hazırlayan ve onu destekleyen basın kuruluşlarının, devlet iktidarı aygıtını elinde tutan siyasal iktidarın karşısında yer alırken, güç sahibi olarak gördükleri devlet aygıtının, yani hegemonyanın aracı durumunda oldukları tespiti yapılabilir. Althusser'in yaklaşımı çerçevesinde ifade edersek, devlet aygıtının (baskıcı devlet aygıtı ve ideolojik devlet aygıtlarının bütün kurumları) bu hegemonyanın tesiri altında darbeye rıza üretiminde bir araç olduğunu söyleyebiliriz.

Türkiye'de hegemonyanın zora dayananı "seküler Kemalizm", rızaya dayananı ise "dinci Kemalizm” olarak kavramsallaştırılabilmektedir (Çaylak, 2014, s. 11-18; Çaylak ve Dinç, 2017, s. 183-184). Çaylak (2018) Kemalist hegemonyanın 'seküler' boyutunun 27 Mayı 1960 Darbesini gerçekleştirdiğini, 'dinci' boyutunun ise 15 Temmuz 2016 Darbe Girişimi’nde bulunduğunu ifade etmektedir (s. 767). Doğan’a (2018) göre de 27 Mayıs Darbesi, aydınlar, sivil-asker bürokratlar, büyük sermaye çevreleri ve CHP seçmeninden oluşan bir "tarihsel blok" tarafından desteklenmiştir (s. 159). Her iki süreçte haber içerikleri ile yapılan rıza üretimi Türk’ün (2017) ve Damlapınar’ın (2002) "Kamusal Senaryo Modeli", izlenen manipülasyon stratejileri ise Herbert Schiller ve Noam Chomsky’nin medya manipülasyonu analizleri çerçevesinde incelenmiştir.

\section{Kamusal Senaryo}

Türk (2017) ve Damlapınar (2002), "Kamusal Senaryo Modeli”nde, medyanın rıza üretimini 8 başlıkta kategorize etmektedir: 
Normalleştirme söylemi: Sholle’nin (1994), var olan durumun olağanlaştırılması diye tarif ettiği "şeyselleşme (reification)" (s. 236), aynı zamanda medyanın 'normalleștirme’ özelliği şeklinde değerlendirilebilir. Çünkü, normalleştirme bir propaganda vasıtası haline getirilerek (Megill, 1998, s. 63), toplumsal ve bireysel rıza üretiminde kullanılabilir. Güç sahibi her kimse, kişinin, vatandaşla devlet arasındaki ilişkileri ve var olan durumu kadermiş gibi kabullenmesini sağlayarak olağanlaştırmıştır (Bauman, 1998, s. 17-19).

Gündemi yönlendirme söylemi: Gazeteler, dergiler, televizyonlar ve radyolar, hakkında konuşulacak konuların dünyasını biçimlendirir ve sadece bununla yetinmez, bu konuların, bireylerin bilinçlerinde önce seçilmesi ve belirlenmesi, ardından da değerlendirilmesi maksadıyla bir içerik kurgular (Sholle, 1994, s. 245). Gündemin genel görünümünü ve gündemde hangi konuların yer alacağını medya belirler (Noelle-Neumann, 1998, s. 177). Medya organları ile iletilen içerikler önceden kabul ettirilmiş mesaj özelliği taşır ve bu içeriklerle, kişilere bütün yapılanların kendileri için olduğu imajı verilir. Kişilerin söz konusu mesajlara inanıp inanmaması çok da mühim değildir (Marcuse, 1968, s. 135).

Kayıtsızlaştırma/siyasetsizleştirmesöylemi: Gazete, televizyonveradyolarıngenişhalkkesimlerinin politikaya katılımını ve ilgisini cezbetmesi umulurken (Tokgöz, 1979, s. 32-33) daha yüksek oranda bir 'siyasete duyarsızlık' geliştirdiğine ilişkin (Tokgöz, 1979, s. 1) görüşler, siyasetsizleştirme kavramına dayanak oluşturmaktadır. Adorno’ya (1998) göre, insanlar artık kamusal süjelere refleks gösterme dürtüsünü kaybetmiştir (s. 68). Dolayısıyla, kamusal senaryonun kayıtsızlaştırma/siyasetsizleştirme yönteminin uygulanmasıyla, siyasi tutkular yerini siyasi tiksinmeye terk etmiştir (Baudrillard, 1998, s. 79).

Bunalımı yaygınlaştırma söylemi: İletişimi sağlayan araçların, iktidarların menfaatlerine olumsuz yansımaları olabilecek bunalım ya da kriz içeren haberleri yayınlaması, sorunun önemsizleştirilmesi ve aynı zamanda yaygınlaştırılmasına hizmet eden bir biçimde gerçekleşir (Herman ve Chomsky, 1988, s. 33). Problemler, söylemler aracilığılla yaygınlaştırıldıkça halkın razı olmasına elverişli bir vasat sağlamaktadır. Baudrillard, (1999) haberleşmenin kontrol altına alınmasından ziyade, haberleşmenin çoğalmasından deva umulması gerektiğini belirtmektedir (s. 97).

Bilgisizleştirme söylemi: Sholle’ye (1994) göre, bilginin denetimi rızayı ve statükoyu oluşturmak amacıyla kullanılır. Bundan dolayı Sholle, rıza üretiminin yanlış bilinç paradigmasıyla açıklanmasına karşıdır; bilginin, üretilerek değil, yok edilerek sisteme rızanın yaratıldığını ve meşruiyet kazandırıldığını savunur (s. 238-240). Ancak çağın ileri teknolojisi düşünüldüğünde, insanı bilgisiz bırakmadan daha önemli olan, bilginin nasıl anlamlandırıldığı ve hangi söylem ya da içerikte sunulduğudur. Neticede, rıza üretiminde, bilgisiz bırakma izlenebilecek önemli stratejilerden birisidir. Gazeteler, televizyon ve radyolar, hatta sosyal medya üzerinden haber görüntüsü ile gerçekte bilgisizleştirici hikâyeler anlatılır (Chomsky, 1995, s.13).

Umut kırma ya da geliştirme söylemi: Erich Fromm’a (1995) göre, umut, "Daha büyük bir canllik, daha büyük bir duyarlllk ve akılcilı sağlamak yönünde gerçekleştirilmek istenen her toplumsal değişimin, belirleyici ögesi”dir (s. 20). Var olan problemlere ilişkin rıza üretiminde umut kadar, 
bireylerin merak etmelerini engelleyeceği için umutsuzluk da (Zeldin, 1998, s. 201) bir yöntem olarak kullanılabilir. Böylece, kamusal senaryonun umut kırma veya geliştirme söylemiyle rıza üretilebilir.

Sivil itaatsizliği kırma söylemi: Çağımızın toplumlarında olaylar insanlara, ne kadar uğraş verilirse verilsin baş edilemeyecek paradokslar veya çözümlenebileceği düşünüldüğünde tekrar bir paradoks yaratan durumlar şeklinde takdim edilmektedir (Bauman, 1998, s. 17). Jean M. Domenach (1995) kitlelerin, sivil direniş, protesto, grev gibi fiillerinin, medya organlarının politik etkilerinden faydalanarak uyutulmasının, durdurulmasının veya gücün yanında olacak şekilde harekete geçirilmesinin sağlanabileceğini belirtir (s. 119). Yani, medya organlarının, olayları uğultudan mırıltıya dönüştürmesiyle, zaten esasen uyumlu davranışlar geliştirmeye eğilimli olan bireylerin sadece "sızlanan bireyler" haline evrilmesi mümkündür (Rigel, 2000, s. 61).

Alternatifsizleştirme söylemi: İtaat edilecek iktidar odağı çoğaldıkça insanın itaat etmesi de zorlaşır (Zeldin, 1998, s. 406). Dolayısıyla, çağımızda genellikle, alternatiflerinin ortaya çıkamaması veya alternatifinin olmadığı kanısının güçlendirilmesi hükümetlerin devamını sağlamaktadır (Mulgan, 1995, s. 19). Rıza gösterenler, alacakları pozisyonun kendileri için en yararlı ya da kaçınılması mümkün olmayan bir pozisyon olduğuna ikna edilmelidir (Canclini, 1999, s. 142). Bu strateji ile gücü elinde bulunduranlar kendi ‘kaçınılmazlarını’ yaratır (Schiller, 1993, s. 15).

\section{Basın ile Manipülasyon Yöntemleri}

Basın organları aracılığıyla geniş halk kesimlerinin hem manevi hem de maddi hedefler istikametinde yönlendirilmesini basın manipülasyonu şeklinde açılayabiliriz. Medyanın manipülasyonu, herhangi bir olay ya da konu hakkında üretilecek habere yapılan müdahale anlamına da gelmektedir ve en fazla sahipliğini holdinglerin yaptığı basın kuruluşlarında görülmektedir (Bülbül, 2001, s. 75). Medyanın manipülasyonu genellikle, enformasyonu çarpitarak aktarma ve aktarılan enformasyonun etkilenmesi amaçlanan duruma ya da fikre meşruiyet kazandırarak devamlı tekrarlanması ve dayatılması yoluyla gerçekleşmektedir.

Bilginin (enformasyonun) çarpıtılarak aktarılması genellikle, enformasyon çarpıtılarak aktarıldığında enformasyonu alan kişinin ya bilgiyi kabul ederek, yani benimseyerek ya da enformasyonu reddederek, yani karşıtlık oluşturarak refleks göstereceği öngörülmektedir. Kişinin gönderilen enformasyonu alması durumu, o kişinin manipülasyona uğratılması anlamına gelmektedir. Kişinin bilgiyi kabul etmesi veya reddetmesi kişinin manipülasyona uğratıldı̆̆ sonucunu değiştirmeyecektir. Örneğin, kişi bilgiyi reddettiğinde manipülasyonla hedeflenen amaç doğru bilginin reddedilmesi olabilir. Aktarılan enformasyonun etkilenmesi amaçlanın duruma ya da fikre meşruiyet kazandırarak devamlı tekrarlanması ve dayatılmasında ise birinci aşamada, yani enformasyonun hedefe ulaşmaması halinde, enformasyonun yinelenerek hedeflenen kitleye ya da kişilere iletilmesi sağlanır. Böylece hedeflenen kitlede ya da bireylerde bir temel görüş, şuur oluşturulur ve manipüle edilmesi amaçlanan özne, kaygıya, korkuya ve şüpheye kapılarak manipülasyona açık bir durum alır. Bu ortamda, birinci aşamaya geri gidilerek, enformasyonun çarpıtılarak aktarılması arzulanan hedefe ulaşmayı mümkün kılacaktır. 
Noam Chomsky'nin on temel stratejisi ve Herbert Schiller Modellemesi, basının manipülasyon süreçlerine ilişkin iki temel önermedir. Chomsky (2011), toplumların üzerine adeta boca edilen manipülasyon stratejilerini şöyle açıklar:

Dikkatin dağıtılması stratejisi: Toplumsal ve sosyal denetim ve kontrolün başlıca ögesidir. Halkın dikkatinin, gücün çıkarlarına aykırı düşecek yahut gücün zayıflaması sonucu doğurabilecek önemli sorunlardan uzaklaştırılması, güç sahiplerinin veya sermayedarların belirlediği gündemin değiştirilmesini sağlamak için, önemsiz ve dikkat dağıtan bilgilerin ve haberlerin akışıyla yönlendirilmesidir.

Yansımadan çok duygusal tarafi kullanma stratejisi: İnsanların duygusal perspektiflerinden faydalanarak, kişinin akla uygun çözümlemesinde ve eleştirel görüşünde çarpışmaya ve çelişkiye yol açan kökleşmiş bir yöntemdir. Bireye bir konu hakkında fikir enjekte etmek, kaygıları, korkuları, istekleri, mecburiyetleri yerleştirmek, istenilen istikamette tutum ve davranış geliştirmek ve o tutum ve davranışa özendirmek amacıyla kişinin şuuraltına erişime imkân sunar.

Erteleme stratejisi: İnsanların duydukları anda reddedecekleri ve kabul etmek istemeyecekleri bir kararın, aslında ne kadar gerekli ve sancılı olduğunun anlatılmasıdır. Farklı bir ifadeyle, toplumda tepki uyandıracak bir kararın uygulanmasından önce, toplumun bunu kabul etmeye ve tepki göstermemeye hazırlanmasıdır.

Kademe stratejisi: Hemen hemen bütün ülkelerde rastlanan bir örnek vermek gerekirse, zaman içinde halkın neredeyse tamamının işsizliğin bitmeyeceği fikrini benimsemiş olması bu stratejinin bir ürünüdür. Halkın reddetmeyeceği bir seviyeye kadar manipülasyon yapılmasını öngörmektedir. Peş peşe ve sistematik yayınlarla, halkın kabul etmesi mümkün olmayan fikirler ve kararlar zaman içerisinde bu strateji ile kabul ettirilir ve benimsetilir. Yavaş yavaş işlenir, aşamalı olarak uygulanır.

Sorun yarat, çözüm sun stratejisi: Bu yöntem, sorun çıkarılmasını, çıkarılan soruna tepki oluşturulmasını ve bu adımlardan sonra da çözümün sunulmasını içermektedir.

Kendini suçlamayı güçlendirme stratejisi: İnsanların, ortaya çıan bir başarısızlıktan dolayı şanssızlıkları, zekâları, kabiliyetleri ve gayretleri bakımından kendilerini suçlamalarının sağlanmasına yönelik bir stratejidir.

Halkın siradanlıktan memnuniyet duymasını sağlama stratejisi: Bu strateji insanların, zekâ yoksunu, ahmak, nezaketsiz, görgüsüz, özensiz, eğitimsiz ve vasıfsız olanın kabul gördüğü gerçeğine inandırılmasını içermektedir. Bununla düşünmeyen, kifayetsiz bireylerden oluşan bir toplum hedeflenmektedir, çünkü onların yönetiminin daha kolay olduğu düşünülmektedir.

Toplumu cahil ve sıradan tutma stratejisi: İnsanları köleleştirmek ve kontrol etmek amacıyla faydalanılan yöntemleri ve teknolojileri anlamaya, bu insanların akıllarının ermeyeceği fikrinin aşılanmasıdır. Örneğin, düşük sosyal statüdekilerin sıradan ve yüzeysel eğitim almaları, böylece üst sosyal statüye çıkamamaları ve planlanan cahillik düzeyinde kalmaları bu stratejinin hedefleri arasinda yer alır. 
Kişileri kendisinden daha çok bilme stratejisi: Özellikle 21. yüzyılın ikinci yarısından itibaren, yaşanan büyük teknoloji dönüşümü ve bilimsel alandaki hızlı gelişmeler, halkın sahip olduğu enformasyon ile seçkinlerin elde ettiği ve işlettiği enformasyon arasında uçurum yarattı. Sistem, vasat düzeydeki bir kişiyi kendisinden daha iyi tanıma noktasına ulaştı. Bu durum, çoğunlukla, sistemin insanlar üzerinde, insanların kendileri üzerinde kurduklarından daha yüksek kontrol sağlamasını ve güç uygulaması imkânını beraberinde getirmektedir.

Topluma küçük çocuk gibi gitme stratejisi: Manipüle yöntemlerinden bir diğeri de, çocuk gibi topluma giderek ve akıllarda çocukmuş gibi yer edinerek, eleştiriden uzak kalmaktır. Eleştiriye kapanma stratejisidir.

Schiller (1993) ise, manipülasyon sürecini 5 ana başlıkta toplayarak şöyle açıklamaktadır (s. 18):

Tarafsızlık: Manipülasyon sürecinin ana unsuru tarafsızlıktır. Geniş halk kesimleri aktarılan enformasyon hakkında, eşitlikçi ve tarafsız bir tutum takınıldığı algısına sahip olmazsa, manipülasyon yapıldığı kuşkusu duyarak, bu da manipülasyonun etkisini azaltacaktır. Bundan dolayı, medya organları devamlı manipülasyonu reddeder, tarafsız, ilkeli ve eşit, çoğulcu yayın yaptıklarını iddia ederler (Schiller, 1993, s. 25).

Bireycilik ve kişisel tercih mitolojisi: Manipülasyon yapacak olanlar, bireyselliği öne alarak geniş halk kesimlerini manipüle ederler. Bunu da daha çok özgürlükler üzerinden gerçekleştirirler, özgürlükle birlikte bireysellik aşılanmaktadır. Bireyle ilgili olanın, bireye özgü olanın özgürlüğün ana unsuru olduğuna ilişkin düşünceler işlenerek, özgürlükle bireyselciliğin eşit olduğu bilincinin yerleştirilmesi hedeflenir. Özel mülkiyetin kutsanması sürecinin başlamasıyla da kişisel hakların ötesine geçilir, insanlar artık özel mülkiyet hakkı için savaşabilecek ve her şeyi yapmayı göze alabilecek bir duruma gelmiştir (Schiller, 1993, s. 20).

Değişmeyen insan tabiatı mitolojisi: Manipülatörler, insanların değişimine inanmaz, bireyin taleplerinin ve isteklerinin değişmeyeceği düşüncesindedirler. Ekonomide ve teknolojide meydana gelen gelişmeler ne kadar büyük farklılıklar getirirse getirsin, tabiatından dolayı insanın sadece basit fonksiyonel değişimleri taşıyacağını, aynı kalacağını savunurlar. Bu sebeple de vatandaşlara devamlı aslında neye ihtiyaçları olduğu ve onsuz olamayacakları düşüncesini kabullendirmeyi amaçlar. Düzen fikrinin ortaya çıkması ve dolaşıma sokulması da buradan kaynaklanır, insanın tabiatı gereği yıkıcı olduğuna vurgu yapılarak, bir düzen kurulması ve bu düzene uyulması düşüncesiyle manipüle eder (Schiller, 1993, s. 27).

Medya çeşitliliği mitolojisi: Bir yerde çeşitlilikten bahsediliyorsa, bu aynı zamanda tarafsılı̆̆ 1 da çağrıştırmaktadır. Medya çoğulculuğunun savunulması, kitle iletişim araçlarının manipülatif bir fiilidir. Yani, medyada programların ve haberlerin birbirinden farklı fikirler alınarak aktarıldı̆̆ görüntüsü ile bilginin tarafsız ve çeşitlilik ilkesine dayanarak iletildiği algısı yaratılır. Böylece aslında verilen, kişinin ne hakkında düşünmesi gerektiğidir (Schiller, 1993, s. 34).

Sosyal çatışmanın var olmaması mitolojisi: Kötü ya da iyi insan kavramları ele alınarak aslında bir sınıf çatışmasının bulunmadığı kanısı yayılır, toplumda sadece iyiler ve kötüler vardır. Egemen sınıfın ve oligarkların devamı için bu görüşün benimsenmesi olmazsa olmazdır. Toplumda bir sınıf 
farklılığının ve sınıf çatışmasının olmadığı, herkesin eşit olduğu düşüncesi aşılanarak, gerçekte yaşanan eşitsizlik görünmez hale gelir (Schiller, 1993, s. 31).

Schiller’e (1993) göre bir diğer manipülasyon yöntemi de haberlerin güncel tutulmasıdır. Güncellikle, bir taraftan sürekli hizmet için gayret gösterildiği, bunun için de saygı duyulması gerektiği fikri oluşturulurken, diğer taraftan da devamlı yapılan bilgi bombardımanıyla insanların bu bilgileri alma ve kavrama yetenekleri zayıflatılmaktadır (s. 46).

\section{Mayıs Darbesi'ne Giden Süreçte Basın}

27 Mayıs 1960 Darbesi’ne giden süreçte basında yer alan haberlerle, kamusal senaryolar arasında sayılan bunalımı yaygınlaştırma, gündem belirleme, normalleştirme gibi söylemler uygulanarak ve haberlerde manipülasyon yoluyla darbeye rızanın nasıl üretildiğine ilişkin dört örnek seçilmiştir.

\section{Zile’de İnönü'ye İtfaiye Hortumuyla Su Sıkıldı̆̆ı İddiası ve Basın}

18 Ekim 1958 günü yayınlanan gazetelerde, 17 Ekim’de Zile’yi ziyaret eden CHP Genel Başkanı İsmet İnönü'yü karşılamaya gelenlere, müdahale edilirken gaz bombası ve cop kullanıldığı, havaya ateş edildiği, İnönü ve bazı milletvekillerinin itfaiyenin hortumla sıktığı sularla ıslandığı haberleri yer almıştır. Ulus gazetesinin 18 Ekim 1958 tarihli nüshası, “Zile’de İnönü’yü karşılayan yurttaşlar bomba ve silahlarla dağıtılmak istendi" manşetiyle çıkmıştır. Cumhuriyet gazetesi, 18 Ekim 1958'de "Zile'de dün müessif hadiseler oldu” manşetinin altında, "Polis ile jandarma, İnönü’yü karşılayan kalabalığı dağıtmak için göz yaşartıcı bombalar attı, cop ve dipçik kullandı, havaya ateş edildi, karışıklık 15 dakika sürdü" spotuyla Zile'de yaşananları aktarmıştır. 19 Ekim 1958'de Ulus gazetesinin birinci sayfasından büyük ve kalın puntolarla "İnönü: Biz, bir ihtilâl ve inkılâp rejiminden geldik" başlıklı haber yer almıştır.

Zile'de çıkan hadiselere ilişkin bu haberlerin nasıl yazıldığını dönemin gazetecilerinden Güngör Yerdeş (2006) anılarında şu ifadelerle anlatmaktadır:

Tokat'tan vakitlice çıkılacak, Zile’ye gidilecek ve akşam da yine dönülecekti. İtibarlı ağabeyimiz dedi ki:

Siz oturun oturduğunuz yerde, ben takip eder, gelir yazar ve sizlere veririm... Bir o gidip geldi Zile’ye. Daktilosunun taktığı sayfaların arasına kopya kâğıtlarını yerleştirip, galiba iki A4’ü dolduracak tespitleri önümüze koyarak, buyurun, geçin gazetelerinize demişti... Gazetelerimize geçtiğimiz haberlerde Tokat ahalisinin tamamının bizlerden duyup önceden öğrendikleri Zile’de neler olmamıştı, neler. Paşanın üstüne arazözlerle sular mı sıkılmamıştı, arabaların lastikleri mi kesilmemişti, kafa ve gözler mi yarılmamıştı... Zile için kendisine güvenip bel bağladığımız yakın çevre gazeteci ağabeyimiz kolumuzu kanadımızı kırmıştı. Sonradan öğrendiğimize göre öyle hortum mortum da pek kesilmemişti. Demokrat Parti’yi böylesine karalayıp gözden düşürmek, yazık günah ve ayıp değil miydi? (s. 38-40)

$\mathrm{Bu}$ olayda, gazetelerin habere yaklaşımı ve sunumu, kamusal senaryolarda yer alan gündemi yönlendirmenin tipik bir örneğini oluşturmaktadır. Ayrıca, bilginin çarpık olarak iletilmesi modeli 
üzerinden medya manipülasyonu yapılırken, Kurtuluş Savaşı’nın komutanları arasında bulunan, yeni devletin kuruluşunda önemli bir rol oynayan İsmet İnönü üzerinden de, Chomsky’nin medya manipülasyonunun stratejileri arasında saydı̆̆ı, yansımadan çok duygusal tarafı kullanma yöntemi uygulanmıştır.

\section{Afyon Emirdă̆’da Yeşil Bayrak Açıldı̆̆ı İddiası ve Basın}

Adnan Menderes'in 19 Ekim 1958'de Afyon'un Emirdağ ilçesi ziyareti sırasında “Nurcuların yeşil bayrak açtı̆̆ı" iddiası dönemin gazetelerinde yer almıştır. Vatan gazetesi 20 Ekim 1958 tarihinde Menderes’in Emirdağ ziyaretine ilişkin haberi, "Menderes dün yeşil bayrakla karşılandı” başlı̆̆ı ile manşetten verirken, haberin spotunda, “...Emirdağ’da bir minareden Başbakanı karşılamak için tuğralı bayrak çekildi” ifadesi kullanılmaktadır. Akşam gazetesinin 20 Ekim 1958 tarihli nüshasında "Menderes: 'Anarşist hareketlere paydos diyeceğiz' dedi” başlığıyla manşetten verilen haberin spotunda, "Emirdağ’da Başbakan Saidi Nursî̀yi selâmladı. Hasan Hüseyin adında bir köylü oğlunu kurban etmek istedi” ifadesi yer almaktadır. "Bu haber hakkında ise Güngör Yerdeş (2006) şunları anlatmaktadir:

İçimizden yine bir ağabeyimiz 'Ben hepinizin adına takip eder, sizlere de yazarım' deyince sanki dünyalar genç meslektaşların oldu. Ankara - Afyon arasını bir toz yumağı halinde tamamlayan gazetecileri, tali köy ve kasaba yollarında kim bilir neler bekliyordu! Cumhuriyet' in kıdemli Ankara muhabirinin bu teklifi hepimizi memnun ve mesut kılmıştı... Evet, Emirdağ ve diğer yerlerdeki karşılamalarda neler olmuştu... Neler mi olmuştu? Kıdemli ağabeyimize göre neler olmamıştı ki... Laik bir memleketin gazetecilerine Başbakanın tekbirli, tespihli, Arapça yazılı bayraklar açılarak, develer, mandalar kurban edilip, sureler okunarak karşılama yapıldığını söylerseniz, üstelik o gazeteciler muhalefetin borazancılı̆̆ını da yapıyorlarsa, o habere dört elle nasıl sarılmazlar... Cumhuriyet muhabiri ağabeyimizin elindeki çoğaltılmışları âdeta kapıştık ve sırası gelen geçti İstanbul’a... (s. 52-54)

$\mathrm{Bu}$ örnek olayda, yine bilginin çarpık olarak iletilmesi ile yapılan medya manipülasyonu tespit edilmektedir. Schiller'in modellemesinde açıkladığı değişmeyen insan tabiatı stratejisine göre, insanın değişimine inanılmamaktadır, manipülasyonu üretenler, kişilerin isteklerinin, inançlarının ve taleplerinin değişmeyeceği, sosyo-ekonomik gelişmeler ne olursa olsun insanın doğası gereği aynı kalacağı izlenimi vermişlerdir. Burada düzen fikri devreye girmekte, "Emirdağda Menderes’i yeşil bayrakla” karşılayanların şeriat taleplerinin değişmediğine yapılan vurguyla, laik düzenin korunması fikri çağrıştırılarak manipülasyon yapılmaktadır. Kamusal senaryo modeli açısından ele alındığında ise, gündemi yönlendirme ve irtica tehdidi ile bunalımı yaygınlaştırma söyleminden yararlanıldığı görülmektedir.

\section{Uşak'ta İnönü'ye Bardak Atıldı̆̆ı İddiası ve Basın}

İsmet İnönü 29 Nisan 1959'da partililer, 48 milletvekili ve büyük bir gazeteci topluluğu eşliğinde Menderes Hükümeti'ne karşı kendi ifadesiyle "Büyük Taaruz"u Uşak’tan başlatmıştır. Cumhuriyet gazetesinin 30 Nisan 1959'da “İnönü’nün Ege gezisi dün hadiseli başladı” manşeti ile verilen haberde, 
İnönü’yü uğurlamak için Ankara garına gelen halka polisin müdahale ettiği, tren Eskişehirden geçerken de polisin gar kapılarını tutarak halkın İnönü’yü karşılamasına mani olduğu aktarılmıştır. Cumhuriyet in 1 Mayıs 1959 tarihli nüshasının manşetinde ise "Uşakta dün müessif hâdiseler oldu" ifadesi yer almakta, altında verilen spotta ise "CHP'liler şehre girerlerken bir Demokrat Partilinin savurduğu bardak İnönü’nün hemen yanındaki bir gazeteciye isabet etti” denilmektedir. Bardak atılma olayının ardından da İnönü Uşak'tan ayrılırken atılan taşın İnönü’nün başına isabet ettiği ve başından yaralandığı iddia edilmiştir.

$\mathrm{Bu}$ haberler, DP’nin dikta rejimi hevesinde olduğunun, otoriterleştiğinin bir kanitı olarak sunulmuştur. Güngör Yerdeş (2006), yıllar sonra bu olayın aslını anlatırken, olayın İnönü ile birlikte gezide bulunan bir gazetecinin tren garında bulunan karşıt görüşlülere eliyle yaptığı provoke edici işaret üzerine yaşandığını açıklamıştır:

Tren yavaş yavaş hızlanıyor. Paşanın bulunduğu koridordayız. Pencerelerin camını indirip âdeta üst üste yığılmış şekilde perondaki Demokrat Partilileri seyrediyoruz. İçimizden biri sağını solunu dirsekleyip bir pencereyi aniden kaplıyor ve sol elinin avcunu açıp uzatarak, sağ elinin başparmağını işaret parmağı ile yüzük parmağının arasından geçirip tokmak şeklinde uzattığı sağ bileğini o sol avcunun içine yerleştirip sıkarak seyretmekte olan Demokratlara 'Naaa!' diye bağırıp başliyor sallamaya... Ve işte bundan sonra başlıyor taşlama... (s. 24-27)

$\mathrm{Bu}$ olayda da gazetecinin bizzat kendisinin haberin oluşumunu sağlayarak kamusal senaryolar bakımından gündemi yönlendirme söyleminden ve yine tarihi bir şahsiyetin başına atılan taş ile yaralanması vakası ile bunalımı yaygınlaştırma söyleminden yararlanılmıştır. Ayrıca, bilginin çarpıtılması ile yine tarihi bir şahsiyetin taşlandığı fikri oluşturularak Chomsky’nin yansımadan çok duygusal tarafı kullanma yöntemi ile manipülasyon yapılmaktadır.

\section{İstanbul Üniversitesi Öğrenci Olaylarında Basın}

İstanbul Üniversitesi’nde 28-29 Nisan 1960'da yaşananlar hakkında iktidarın yayın yasağı koyması, kamusal senaryonun bunalımı yaygınlaştırma söyleminde, Baudrillard’ın (1999) haberleşmenin denetlenmesinden değil, fazlalaşmasından çare umulması gerektiğine ilişkin tezini (s. 97) doğrular niteliktedir. Yayın yasağının da etkisiyle, sadece söylenti olarak olaylarda yüzlerce öğrencinin öldügüu, yaralıların bilinmeyen yerlerde hapsedilerek ölüme terkedildiği haberleri bütün yurda yayılabilmiştir. ${ }^{1}$ Bu iddianın asılsız olduğu ancak darbenin ardından Milli Birlik Komitesỉnin kendisinden haber alınamayan öğrencilerin ailelerinin müracaat etmelerine ilişkin çağrısı üzerine hiçbir müracaat gelmemesiyle anlaşılabilmiştir. Yüzlerce öğrencinin öldürüldüğü iddiasıyla, gündem tamamen İstanbul Üniversitesi’ndeki olaylara yönlendirilmiş, belirsizlik yaratılarak, karmaşıklık artırılarak, üstü örtülü verilen veya yayın yasağından dolayı yapılamayan haberlerle bunalım yaygınlaştırılmıştır.

1 O gün üniversitede yaşanan olaylar için bkz. Başgil (2011). 


\section{Mayıs 1960'ta Ulusal Basin}

27 Mayıs Darbesi’nin gerçekleşmesinin ardından basının, darbeyi meşrulaştırmak üzere bir yayın politikası izlediği, tutuklanan DP’lilerin gerçek dışı iddialarla henüz yargılanmamış olsalar da suçlu ilan edildikleri söylenebilir. Akis dergisinin 30 Mayıs 1960 tarihli Menderes’in üzerine çarpı işareti konulmuş fotoğrafı ile birlikte “Adnan Menderes Sabık Başbakan” kapağ dönemin simgesi olmuştur. Milliyet gazetesinde "Sabık Cumhurbaşkanı 1500 Harbiyelinin imhasında hiç mahzur olmadığını söylemiş” (1960a), "Menderes 10 yılda 480 bin lira maaş ve tazminat almış Sabık Başbakanın 1954 ve 1957 seçimlerinde yaptığ propaganda gezileri için de yolluk aldığ 1 tespit edildi” (1960b), Akşam gazetesinde, "K. Aygün, belediye tahvillerini kırdırıp kendi hesabına toplamış. Bekçi aidatlarının da yenildiği anlaşılıyor" (1960a), "Bayar kahve ithali işinde de ortakmış” (1960b) başlıklı haberlere yer verilmiştir.

Bu haber örneklerinde, kamusal senaryolardan normalleştirme söylemi, gündemi yönlendirme söylemi, siyasal konuların kitle iletişim araçları tarafından sınırlandırılması ile siyasetin alt yapısını oluşturmasını içeren siyasetsizleştirme söylemi, bilginin kontrolü ile rızanın oluşturulmasını hedefleyen bilgisizleştirme söylemi, basın aracılığıyla insanların sızlanmadan öteye geçmeyen bireyler haline getirilmesini öngören sivil itaatsizliği kırma söyleminin kullanıldı̆̆ı görülmektedir.

Ayrıca söz konusu haberler, bilginin çarpık olarak iletilmesi ile yapılan manipülasyonun da bir örneğini oluşturmaktadır. Chomsky'nin medya manipülasyonunun on stratejisi arasında yer alan, dikkat dağıtma (siyasal değişim, yani hükümet darbesinden dikkatin dağıtılması), sorun yarat, çözüm sun (bir sorun çıkarılması, tepki oluşturulması ve çözüm olarak darbenin sunulması), erteleme (kabul edilemeyecek bir kararı sancılı ve gerekli olarak sunma), toplumu cahil ve sıradan tutma, kendini suçlamayı güçlendirme (kişilerin talihsizliği, zekâsı, yetenek ve çabaları yönünden başarısızlığı için kendini suçlamasına yol açılması) stratejilerinin kullanıldığ görülmektedir.

\section{Uluslararası Basın ve 27 Mayıs 1960}

27 Mayıs’ın ardından yapılan Yassıada Duruşmaları'nın gerekçeli kararı yıllar sonra açıklanmış, açıklandığında ise uluslararası medyada yer alan haberlerin Adnan Menderes ve iki bakanın idamı kararında delil olarak sunulduğu ortaya çıkmıştır. Gerekçeli kararda delil olarak sunulan, uluslararası basın kaynaklı yazılar, haberler ve açıklamalardan bazı örnekler aşağıda verilecektir (Yüksek Adalet Divanı Gerekçeli Kararları, 1960-1961):

Delillerden ilki, Amerika Dış İlişkiler Komisyonu Başkanı Senatör J. William Fulbright’ın (19051995) 1 Mayıs 1960’ta CBS Televizyonu’nda yaptığı, “Bugünkü Türk hükümetinin diktatöryal tutumunu ilk defadır fark etmiş değilim” diye başlayan şu cümleleridir:

İktidara gelişlerinden pek az sonra gazeteleri kapatmaya başladılar...Kemal Atatürk yeni bir azimle Türkiye'yi yeniden yarattı. Ondan sonra gelenler çok akıllıca bir hareketle serbest seçimler yaparak muhalefetin iktidarı almasına müsaade ettiler. Bu büyük bir devlet adamlığıdır. Halbuki şimdi iktidar partisi başlanan teamül üzerine gideceği yerde muhalefeti hapse atmaktadır. Zannederim bu, gelişmenin zıddı bir tutumdur. 
İtalya'da yayımlanan II Corriere Della Sera gazetesinin 30 Nisan 1960 tarihli sayısındaki “Türkiye’de dram” başlıklı yazıda şunlar ifade edilmiştir:

...ve işte diğer bir demokratik kötü dönüş, Batista’dan Syngman Rhee'den sonra şimdi Menderes'in sırasıdır. Demokrasiden istibdada (despotizme) istihale (değişim) her zaman aynıdır. Hürriyet isteyerek ve vaat ederek iktidar fethedilir ve sonra iktidarı muhafaza etmek için hürriyet 'inkâr' edilir...

İngilterede yayımlanan The Guardian gazetesi Yazişsleri Müdürlügüu’ne 18 Mayıs 1960'ta Rose Mary adlı bir Amerikalı’nın Teksas'tan gönderdiği mektupta şu ifadeler yer almaktadır:

Beyefendi, Türk Hükümeti’nin Türk vatandaşları aleyhindeki hareketlerini desteklememiz İngilizce konuşan bütün milletlerin hürriyet ananelerine ve Kuzey Atlantik Paktı Teşkilatı ile alakalı bütün milletlerin hürriyet ananelerine aykırıdır. İstanbulda akdedilen NATO konferansına temsilcilerimizi göndermek suretiyle tamamen bu hareketi desteklemiş oluruz. Ve buna ilaveten Menderes Hükümeti tarafından Türk halkına yapılan zulmü NATO mefhumlarına uygun telakki ettiğimiz zannını vermekteyiz...

İngilterede yayımlanan 30 Nisan 1960 tarihli Daily Telegraph gazetesinin 26. sayfasında şu görüşler dile getirilmektedir:

Menderes Hükümetỉnin, parlamenter sistemin esasını teşkil eden muhalefet hürriyetini yok etmek yolunda çalıştığına aşağı yukarı şüphe kalmamıştır. Hakikatte Türkiye bir diktatörlüğü parlamenter bir sisteme çevirmenin delillerini dünyaya göstermiştir...

$\mathrm{Bu}$ haber, yorum ve yazılar incelendiğinde, Başbakan Adnan Menderes’e yönelik diktatörlük iddiasının sistematik olarak işlenmesiyle manipülasyonun, iletilen bilginin ulaşılması hedeflenen görüşe veya duruma meşruiyet kazandırılarak sürekli olarak tekrarlanması ve dayatılması yönteminin yanı sıra Schiller modellemesinde bulunan kişisel tercih ve bireyselcilik yöntemine (Schiller, 1993, s. 20) de rastlamaktayız. Buna göre, manipülasyonun uygulayıcıları, bireyselliği ön plana çıkararak kitleleri manipüle etmektedir, "özgürlük” kavramı ele alınarak da kitleler üzerinde bireyselcilik aşılanmaktadır.

Chomsky'nin medya manipülasyonunun on stratejisi bakımından incelendiğinde ise bu haberlerde, dikkat dağıtma (siyasal değişim, yani hükümet darbesinden dikkatin dağıtılması), sorun yarat, çözüm sun (Bir sorun çıkarılması, tepki oluşturulması ve çözüm olarak darbenin sunulması), erteleme (kabul edilemeyecek bir kararı sancılı ve gerekli olarak sunma), kendini suçlamayı güçlendirme (kişilerin talihsizliği, zekâsı, yetenek ve çabaları yönünden başarısızlığı için kendini suçlamasına yol açılması) stratejilerinin kullanıldığı görülmektedir. Ayrıca, kamusal senaryolardan normalleştirme, gündemi yönlendirme, siyasetsizleștirme söylemlerinin, bilginin kontrolü ile rızanın oluşturulmasını hedefleyen bilgisizleştirme söyleminin, basın aracılığıyla insanların sızlanmadan öteye geçmeyen bireyler haline getirilmesini öngören sivil itaatsizliği kırma söyleminin kullanıldığını söyleyebiliriz. 


\section{Temmuz 2016 Darbe Girişimi Öncesinde Basın}

15 Temmuz’a giden süreç de basında yer alan haberlerin içeriği 27 Mayıs 1960 Darbesi’ne giden süreçteki haberlerin içeriğiyle benzerlik taşımaktadır. 15 Temmuz Darbe Girişimi’ne giden süreç, "Gezi olayları", "17-25 Aralık yolsuzluk iddiaları” ve "2014 Cumhurbaşkanlığı seçimleri öncesi” dönemlerde, Cumhuriyet, Hürriyet ve Milliyet gazetelerinin yayınları ve etkin uluslararası medya kuruluşlarının yaklaşımları üzerinden incelenmiştir.

\section{Gezi Olayları'nda Uluslararası ve Ulusal Basın}

27 Mayıs 2013’te başlayan Gezi olayları, uluslararası ve ulusal basında birbirine benzer dil ve söylem içerikleri ile kamuoyuna aktarılmıştır.

\section{Uluslararası Basında Gezi Olayları}

Erdoğan’a yönelik diktatör ve otoriterleşme iddiası, Gezi olayları ile birlikte uluslararası basın kuruluşlarında, özellikle de ABD basınında yoğun bir şekilde yer almaya başlamıştır. Örneğin Seyla Benhabib (2013), The New York Times’ta yayımlanan “Türkiye’nin Otoriter Dönüşü” başlıklı yazısında, "2011'de üçüncü dönem için yeniden seçilen Erdoğan, aldığı yetkiyi birçoklarının Osmanlı İmparatorluğu’nun yıkılmasından sonra kurulan seküler cumhuriyete saldırı olarak gördüğü otoriter bir gündemi takip etmek için kullandı” değerlendirmesini yapmıştır. Yine The Washington Post'un yazı işleri müdürlügünce, “Başbakan Erdoğan’ın Türkiye’deki protestolara güçlü adam tepkisi” başlıklı yazısında, "Erdoğan, hem seçilmiş hem otoriter olmanın mümkün olduğunun talihsiz kanıtlarını sunuyor” yorumu yapılmıştır (Editorial, 2013). Bir gün sonra, CNN'de Ivan Watson ve Josh Levs'in (2013) hazırladığı “Erdoğan: Başarılı bir lider veya diktatör?” başlıklı haberde, Erdoğan’ın başarılı bir lider mi yoksa diktatör mü olduğu tartışması açılmıştır.

\section{Ulusal Basında Gezi Olayları}

Gezi olayları, Erdoğan yönetiminin karşı karşıya kaldığı ilk büyük toplumsal eylem olma niteliği taşımaktadır. Ulusal gazeteler bu olayları şöyle yansıtmıştır:

Cumhuriyet gazetesi, 29 Mayıs 2013’te Erdoğan fotoğrafı eşliğinde, “Son durağa doğru” manşeti ile çıkmış, haberin altında ise Gezi'de başlayan protesto haberini polislerin kırmızı elbiseli bir kadına su sıkarken çekilmiş fotoğraflarıyla birlikte vermiştir. 31 Mayıs 2013 tarihli nüshasında, gazdan kaçan genç insanların fotoğrafı manşete taşınarak, "Halk direniyor”, 1 Haziran 2013’te eylemcilere hortumla sıkılan su fotoğrafı eşliğinde "Halk başkaldırdı", 3 Haziran 2013’te ise "Halkla çatışıyor" başlı̆̆1 ile haberler verilmiştir. İlerleyen günlerde, 13 Haziran'da Cumhuriyet gazetesinin birinci sayfasından avukatların çeşitli şehirlerde düzenledikleri mitinglere ilişkin haber "Demokrasi için ayağa kalktılar” başlı̆̆ı ile verilirken, günlerce işlenen şiddet, vahşet teması yerini artık, demokrasi, özgürlük temasına bırakmıştır. 17 Haziran 2013'te ise Cumhuriyet gazetesinin manşeti “Halk baskıya ve zulme direniyor" olmuştur, birinci sayfadan eylemcilere polis ve jandarmanın terör uyguladığı konusu işlenmiştir. Cumhuriyet gazetesinin, olayları yansıtırken, Erdoğan yönetiminin, şiddeti teşvik 
eden, baskıcı, otoriter bir yönetim olduğu, Erdoğan’’n diktatörlüğe yöneldiği söylemini yapılandırdığı görülmektedir.

Hürriyet gazetesi, 31 Mayıs 2013'te manşet altından verdiği "Gezide yıkma timi” haberinin ardından, 1 Haziran 2013’te eylemcilere biber gazı ve su sıkılan büyük bir fotoğraf eşliğinde "Gazi Parkı" manşeti ile çıkmıştır. 2 Haziran 2013’te Hürriyet gazetesi eyleme katılan gençlerin fotoğraflarının derlemesi üzerine “\#5gündetaksim”, 6 Haziran 2013’te İzmir'de sosyal medya üzerinden yaptıkları çağrılarla halkı isyana teşvik ettikleri iddiasıyla 34 kişinin gözaltına alınmasını "Sosyal gözaltı" başlı̆̆ ile manşete taşımıştır. Hürriyet, 12 Haziran 2013’te birinci sayfanın üçte ikisini kaplayacak büyüklükte, Taksim Meydanı’nda saat 20:15’te çekilen eylemcilere müdahale fotoğrafı eşliğinde, "Yazık" manşeti ile çıkmıştır. Haberlerde, "okumuş genç çocuklara" karşı, güvenlik güçlerinin orantısız şiddet uyguladığı mesajı işlenirken, Erdoğan yönetiminin, "baskıcı bir yönetim" olduğu iddia edilmektedir.

Milliyet gazetesi, 29 Mayıs 2013’te polisin sıktığı suya karşı kırmızı elbisesi ile duran kadının fotoğrafıyla birlikte "Mutsuzluğun resmini çizdik" manşeti ile çıkmıştır. Milliyet gazetesi, 1 Haziran 2013’te "Ne bu şiddet bu celal" başlığı ile Gezi Parkı’nda yaşanan olayları manşetine taşımıştır, haber Taksim Meydanı’nın toz ve gaz bulutu içinde kaldığını gösteren büyük bir fotoğraf eşliğinde kullanılmıştır. Milliyet gazetesinin de Türkiye'de şiddet, otoriterlik, diktatörlük, özgürlükleri kısıtlayan bir iktidar olduğu söylemine, bu fotoğraf ve haberlerle katkı sağladığı tespiti yapılabilir.

\section{7-25 Aralık Sürecinde Uluslararası ve Ulusal Basın}

Erdoğan’a yöneltilen “diktatörlük", "otoriterlik” eleştirilerine, Mart 2014 yerel seçimleri öncesinde, 17-25 Aralık 2013’te Fetullahçı Terör Örgütü (FETÖ) mensubu oldukları ortaya çıkan bazı polis ve savcıların, Erdoğan’n yakın çevresine ve bakanlara yönelik başlattıkları operasyonlara ve özellikle sosyal medya kanalıyla yayılan ses kayıtlarına dayandırılan "yolsuzluk" suçlamaları eklenmiştir.

\section{Uluslararası Basında 17-25 Aralık}

17-25 Aralık 2013’te sosyal medyada dolaşıma sokulan yolsuzluk iddiası uluslararası medyanın önemli gündem maddelerinden birisi olmuştur. Alexander Christie-Miller'in (2013) The Times'ta yayımlanan "Yolsuzluk skandalına karışan Erdoğan’a bırakma çağrısı" başlıklı yazısında Erdoğan yönetimine yönelik yolsuzluk iddiaları, doğruluğu teyit edilmemiş ve soruşturma süreçleri tamamlanmamış olsa da gerçekmiş gibi verilerek Erdoğan'dan görevini bırakması istenmektedir. Time'da, Courtney Subramanian (2013) imzasıyla ve "Türk lider yolsuzluk soruşturmasına kızdı" başlı̆̆ ile Türkiyede yaşananlar aktarılmıştır. The Washington Post'ta Joshua Tucker (2013) imzasıyla yayımlanan “ Türkiye’yi konuşmak: Yolsuzluk seçmen davranışını nasıl etkiliyor?” başlıklı yazıda ise kanıtlanmış ve kesinleşmiş gibi sunulan "yolsuzluk” un 2014’te yapılacak seçimlerde oy davranışını nasıl etkileyeceği ele alınmıştır. 


\section{Ulusal Basında 17-25 Aralık}

Cumhuriyet gazetesi, 18 Aralık 2013’te bakanların ve gözaltına alınan bir bakan oğlunun fotoğrafı eşliğinde tam sayfa "Pimi çektiler" manşeti ile çıkmış, haberin üst başlı̆̆ında, "Yolsuzluk iddiasıyla büyük operasyon: Bakan çocukları, bürokratlar, işadamları, bankacıların da aralarında bulunduğu 52 kişi gözaltına alındı" ifadesi kullanılmıştır. Haber, 19 Aralık 2013’te "Rezalet diz boyu” başlığı ile yine manşetten devam ettirilmiştir. Cumhuriyet' in 10 Ocak 2014’te "Çırpındıkça batıyor" başlığ ile manşetten verilen haberinde, iktidarın soruşturmalardan kurtulmak için otoriter yönetimlerin taktiklerine sarıldığı ifade edilmektedir. Cumhuriyet gazetesinde, 21 Şubat 2014’te, “Demokrasi ve özgürlükleri askıya alan yasalarla kararlar arka arkaya dizildi” üst başlı̆̆ının altında Erdoğan fotoğrafı eşliğinde “Farkında mısınız?” sorusu manşetten yöneltilmiştir.

Hürriyet gazetesinin 19 Aralık 2013’te sürmanşetten “Savcıdaki fotoğraflar” başlığı ile verdiği haberde, fotoğraflar eşliğinde "Büyük rüşvet adlı operasyon öncesi teknik takip yapan polis, işadamı Reza Zarrab ile yanında çalışan Ahmet Murat Öziş̧in kutular ve çantalarda farklı adreslere taşıdığ paraları görüntüledi” spotu yer almaktadır. 23 Aralık 2013’te "Parayı vekilin oğlu getirdi” başlı̆̆ ile manşetten verilen başka bir haberde, "Polisin 'büyük rüşvet' operasyonunda tutuklanan Halkbank Genel Müdürü Süleyman Aslan, ayakkabı kutularındaki 4,5 milyon doları anlatırken İstanbul Milletvekili H.B’yi adres gösterdi” spotu kullanılmıștır. Gazetenin 26 Aralık 2013 tarihli "3 Baba gitti” başlı̆̆ ile manşetten verdiği haberin spotunda ise, “'Büyük rüşvet' operasyonu kapsamında 17 Aralık'ta çocukları gözaltına alınıp ikisininki tutuklanan 3 bakan dün istifa ettiklerini açıkladı" ifadeleri kullanılmıştır. Bu haberlerde, gazetenin operasyonu sistematik biçimde, "Büyük rüşvet operasyonu" tanımıyla vermesi ve bütün haberlerinde bu tanımı tekrar etmesi, operasyonun bu şekilde akıllarda yer etmesine yönelik bir sunum olarak değerlendirilebilir.

Milliyet gazetesinde 18 Aralık 2013 tarihinde, "Rüşvet ve yolsuzluk soruşturmasında 49 kişi suçlanıyor" üst başlığının altında "Şok operasyon" manşetiyle verilen haberin spotunda, İstanbul Başsavcıllğı̉nın talimatıyla harekete geçen mali polisin 3 bakanın oğlunu, işadamlarını ve bir grup bürokratı gözaltına aldığı bilgisi paylaşılmaktadır. 19 Aralık 2013 tarihli “Paralar saçıldı” başlığı ile manşetten verilen başka bir haberin üst başlığında " 17 Aralık operasyonunda aranan evlerde balya balya döviz bulundu" ifadesi yer almış, haberin spotunda ise " 3 bakanın oğlu ile işadamlarının adının karıştığı yolsuzluk operasyonunda polisin baskın görüntüleri ortaya çıktı. Milyonlarca doların nakit halde saklanması dikkat çekti” denilmiştir.

Gazeteler, Başbakan Erdoğan’ın “17-25 Aralık yargı ve polis darbesi” söylemine karşın, düzenli ve tekrar eden bir şekilde olayı "yolsuzluk ve rüşvet operasyonu” ifadesiyle tanımlamaktadır. Haberlerde bu tanımın ya kırmızı renkle belirginleştirerek ya üst başlıklarda ya da spotlarda vurgulanması ile, "yolsuzluk ve rüşvet" iddiasının üretilmesine ve pekiştirilmesine, kamuoyunun buna ikna edilmeye çalışılmasına ilişkin bir manipülasyon stratejisini içerdiği tespiti yapılabilir. 


\section{Cumhurbaşkanlığı Seçimleri Öncesinde Ulusal ve Uluslararası Basın}

Başbakan Erdoğan, 10 Ağustos 2014’te ilk kez halkoyu ile gerçekleşen cumhurbaşkanlığ seçimlerine de kendisine yöneltilen "diktatörlük", "otoriterlik" ve "yolsuzluk" suçlamaları eşliğinde gitmiştir.

\section{Uluslararası Basında 2014 Cumhurbaşkanlığı Seçimleri}

Robert Fisk (2014), The Independent'ta yayımlanan "Recep Tayyip Erdoğan model bir güçlü adamdan teneke diktatöre mi dönüştü?” başlıklı yazısında, “Öyleyse Orta Doğu’nun başka bir ‘güçlü adamı' daha teneke diktatör 've tehlikeli' haline mi geldi? Veya muhafazakâr, sağduyulu bir demokrat aniden gerçek renklerini mi gösterdi?” sorularını yöneltmiştir. Alexander Christie-Miller’in (2014) The Times'te yayımlanan "Türkler çarpık bir yarışın Erdoğan’ı diktatör olarak kutsamasından korkuyor” başlıklı yazısında ise, “Türkiye Başbakanı, devlet televizyonunun rakiplerinin yayınlarını dondurduğu başkanlık yarışında zafere doğru seyrederken ülkedeki otoriter tutumunu sıkılaştıracağı görünüyor. Eleştirmenler, Recep Tayyip Erdoğan’ın neredeyse kesin olan zaferi ile iktidarın bütün gücünün onun elinde toplamasından korkuyor” görüşü ifade edilmiştir. Yazıda, bir taksi şoförünün "Erdoğan şimdi kral” ve "Güçlü bir hükümet istiyoruz ancak diktatörlük istemiyoruz" dediği aktarılmaktadır.

\section{Ulusal Basında 2014 Cumhurbaşkanlığı Seçimleri}

10 Ağustos 2014 tarihinde gerçekleşen cumhurbaşkanlığı seçimleri öncesinde, Cumhuriyet gazetesi 13 Nisan 2014 tarihli haberinde "CHP lideri dosyaların peşini bırakmayacakları mesajı verdi” üst başlığının altında "Yolsuzlukları ispatlayacağız” manşeti ile çıkmıştır. 23 Nisan 2014 tarihli bir başka haberde, “Olağan salı toplantılarında eleştiri okları Başbakan’a yöneldi” üst başlığı altında “17-25 Erdoğan” manşeti yer almaktadır. 1 Haziran 2014’te “Gezi’nin yıldönümünde yine sıkıönetim uygulandı, polis terör estirdi” üst başlığının altında "A’dan Z’ye vahşet” manşeti kullanılırken, 2 Ağustos 2014'te “Cumhuriyet üstü örtülen 25 Aralık yolsuzluk dosyasını açıyor” üst başlı̆̆ının altında Başbakan Erdoğan, oğlu Bilal Erdoğan ve Suudi Arabistanlı işadamı Yasin El Kadı’nın fotoğrafı eşliğinde "Arkadaşın babası" manşeti ile birkaç gün üst üste manşetten yayınlanacak dizi haberin başladığı duyurulmuştur. 9 Ağustos 2014 tarihli seçimlerden bir gün önceki nüshada ise, “Tek adam mı demokrasi mi?” manşetiyle çıkılmıştır.

Hürriyet gazetesi 2 Mayıs 2014'te ağlayan ve polisin kullandığı biber gazından etkilenen çocukların fotoğrafları eşliğinde, "Bugün bayram, gazdan kaçın çocuklar” ikinci manşeti ile çıkmıştır. 6 Mayıs 2014 tarihli nüshada "Kürsüde inkâr" başlığı ile ikinci manşet olarak verilen haberin spotunda, “Tapelerle ortaya çıkan yolsuzluk ve rüşvet iddiaları, Meclis’te konuşuldu. Genel Kurul'da kürsüye çıkan 3 eski bakan iddiaların yalan olduğunu öne sürdü. Hakkında takipsizlik verilen Erdoğan Bayraktar, savunma hakkını kullanmadı” ifadeleri yer almıştır. Gazetenin bu haberi kullanırken seçtiği "inkâr” kelimesi dikkat çekicidir. 
Milliyet gazetesi ise, 2 Mayıs 2014 tarihinde “1 Mayıs kalesi” başlı̆̆ 1 ile manşetten verilen haberin spotunda, “İstanbul'da polis 1 Mayıs'i Taksim'de kutlamak isteyenleri yine biber gazı ve suyla durdurdu. Ankara'da ise Kızılay’a geçişi engellemek için kurulan 18 metre genişliğindeki metal 'mavi kale’ görenleri şaşırttı” ifadesini kullanmaktadır. Gazete, 6 Mayıs 2014’te “4 bakana 1 komisyon” başlı̆̆ CHP’nin Çağlayan için ayrı komisyon istemesi kavga çıkardı. Oylamayla tek komisyon kuruldu” ifadelerini kullanmış, haber Mecliste çıkan kavganın fotoğrafı ile verilmiştir.

Erdoğan, 10 Ağustos 2014 tarihinde ilk kez halk tarafından yapılan cumhurbaşkanlığı seçimlerinde, birinci turda oyların yüzde 51,7'sini alarak cumhurbaşkanı seçildi ancak bu sonuç, kendisine yöneltilen diktatörlük ve otoriterlik eleştirilerine son vermedi. Bu yayın organlarında, sistematik bir şekilde otoriterlik ve diktatörlük suçlamalarının 15 Temmuz’a kadar devam ettiğini görmekteyiz.

15 Temmuz Darbe Girişimi’ne giden süreçte, üç dönemde ele alınan gerek ulusal gerekse uluslararası basında yer alan haberler, yorum ve yazılar incelendiğinde, 2013 yılında Başbakan olan, 2014 yılında ise Cumhurbaşkanı seçilen Recep Tayyip Erdoğan’a yönelik, "yolsuzluk", "diktatörlük", "otoriterlik", "fikir ve ifade hürriyetine baskı" iddiasının sistematik olarak işlenmesiyle manipülasyonun, iletilen bilginin ulaşılması hedeflenen görüşe veya duruma meşruiyet kazandırılarak sürekli olarak tekrarlanması ve dayatılması yönteminin yanı sıra Schiller modellemesinde bulunan kişisel tercih ve bireyselcilik yöntemine (Schiller, 1993, s. 20) de rastlamaktayı.

Chomsky'nin medya manipülasyonunun on stratejisi bakımından incelendiğinde ise bu haberlerde, dikkat dağıtma (siyasal değişim, yani hükümet darbesinden dikkatin dağıtılması), sorun yarat, çözüm sun (Bir sorun çıkarılması, tepki oluşturulması ve çözüm olarak darbenin sunulması), erteleme (kabul edilemeyecek bir kararı sancılı ve gerekli olarak sunma), kendini suçlamayı güçlendirme (kişilerin talihsizliği, zekâsı, yetenek ve çabaları yönünden başarısızlığı için kendini suçlamasına yol açılması) stratejilerinin kullanıldığı görülmektedir. Ayrıca, kamusal senaryolardan normalleştirme, gündemi yönlendirme, siyasetsizleştirme söylemlerinin, bilginin kontrolü ile rızanın oluşturulmasını hedefleyen bilgisizleştirme söyleminin kullanıldığını söyleyebiliriz.

\section{Sonuç}

27 Mayıs 1960 Darbesi ve 15 Temmuz 2016 Darbe Girişimi’ne giden süreçlerde, cumhuriyet modernleş(tir)mesinin katı bir laisizm ve etnik temelli bir milliyetçilik anlayışını içeren ve cumhuriyetin kuruluş felsefesi olarak da tanımlanabilecek “devlet ideolojisi”ne dayanan hegemonyanın aygıtlarından olan basında, yer alan haber içerikleriyle darbeye rıza ve meşruiyet kazandırılmaya çalışıldığı görülmektedir.

27 Mayıs 1960 Darbesi’ne giden süreçte, İnönü’nün Zile ziyaretinde yaşanan olaylar, Menderes’in Afyon Emirdağ ziyaretinde yeşil bayrak açıldığı iddiası, İnönü’nün "Büyük taarruz” olarak nitelendirilen yurt gezilerini başlattığı Uşak’ta kendisine DP’lilerin bardak, taş attığ 1 , başından yaralandığg iddiası ve İstanbul Üniversitesi’nde yaşanan olayların basına nasıl yansıdığı araştırılmıştır. 
İsmet İnönü’nün Zile ziyaretine ilişkin, aslında orada muhabiri bulunmayan gazetelerin haberleri yansıtma biçimi, literatürde belirtildiği üzere, Türk ve Damlapınar’ın kamusal senaryo modelinde yer alan gündemi yönlendirmenin tipik bir örneğini oluşturmaktadır. Ayrıca, bilginin çarpık olarak iletilmesi modeli üzerinden medya manipülasyonu yapılırken, Kurtuluş Savaşı’nın komutanları arasında bulunan, yeni devletin kuruluşunda önemli bir rol oynayan İsmet İnönü üzerinden de, Chomsky’nin medya manipülasyonunun stratejileri arasında saydığı, yansımadan çok duygusal tarafi kullanma yöntemi uygulandığı sonucuna ulaşılmıştır.

Başbakan Adnan Menderes'in Emirdağ ziyaretinde yeşil bayrak açıldığı yönündeki haberlerde, yine bilginin çarpık olarak iletilmesi ile yapılan medya manipülasyonu tespit edilmektedir. Schiller'in modellemesinde açıladığı değişmeyen insan tabiatı stratejisine göre, insanın değişimine inanılmamaktadır, manipülasyonu üretenler, kişilerin isteklerinin, inançlarının ve taleplerinin değişmeyeceği, sosyo-ekonomik gelişmeler ne olursa olsun insanın doğası gereği aynı kalacağ izlenimi verilir. Burada düzen fikri devreye girmekte, "Emirdağda Menderes’i yeşil bayrakla" karşılayanların şeriat taleplerinin değişmediği mesajı ile düzenin korunması fikri enjekte edilerek manipülasyon yapılmaktadır. Türk ve Damlapınar’n kamusal senaryo modeli açısından ele alındığında ise, gündemi yönlendirme söylemi ile rıza üretimi yapıldığı görülmektedir.

İnönü’nün “Büyük Taaruz”u başlattığı Uşak’ta tren garında kendisine taş, bardak atıldığı ve başından yaralandığı iddialarına yol açan olayları gazetelerin aktarışı incelenmiştir. Gazetecinin bizzat kendisinin haberin oluşumunu sağlayarak, Türk ve Damlapınar’n kamusal senaryo modelindeki, gündemi yönlendirme söyleminden ve yine tarihi bir şahsiyetin başına atılan taş ile yaralandığı işlenerek bunalımı yaygınlaştırma söyleminden yararlanıldığı sonucuna ulaşılmaktadır. Ayrıca, bilginin çarpitılması ile yine tarihi bir şahsiyetin taşlandığı fikri oluşturularak Chomsky’nin yansımadan çok duygusal tarafı kullanma yöntemi ile manipülasyon yapıldığı tespit edilmektedir.

İstanbul Üniversitesi’nde 28-29 Nisan 1960'da yaşananlar tarihi bir manipülasyon örneği niteliği taşımaktadır. İktidarın yayın yasağı koyması üzerine, örneğine çok az rastlanabilecek bir manipülasyon stratejisi izlenirken, Baudrillard'ın (1999) haberleşmenin denetlenmesinden değil, fazlalaşmasından çare umulması gerektiği tezi (s. 97) doğrulanmaktadır. Gündem tamamen İstanbul Üniversitesi'ndeki olaylara yönlendirilmiş, üstü örtülü yapılan ya da yayın yasağı sebebiyle yapılamayan haberlerle, belirsizlik yaratılarak, karmaşıklık artırılarak bunalım yaygınlaştırılmıştır. Bilginin çarpıtılması ile yapılan manipülasyona da bu olayın bir örnek oluşturduğu söylenebilir.

27 Mayıs Darbesỉnin gerçekleşmesinin ardından basının, darbeyi meşrulaştırmak üzere bir yayın politikası izlediği, tutuklanan DP'liler gerçek dışı iddialarla henüz yargılanmamış olsalar da suçlu ilan edildikleri söylenebilir. Akis dergisinin 30 Mayıs 1960 tarihli Menderes'in üzerine çarpı işareti konulmuş fotoğrafı ile birlikte "Adnan Menderes Sabık Başbakan" kapağı dönemin simgesi olmuştur. Akşam gazetesinde 12 Temmuz 1960'da "K. Aygün, belediye tahvillerini kırdırıp kendi hesabına toplamış. Bekçi aidatlarının da yenildiği anlaşılıyor", Milliyet gazetesinde 13 Temmuz 1960'da "Sabık Cumhurbaşkanı 1500 Harbiyelinin imhasında hiç mahzur olmadığını söylemiş" ve "Menderes 10 yılda 480 bin lira maaş ve tazminat almış. Sabık Başbakanın 1954 ve 1957 seçimlerinde 
yaptığı propaganda gezileri için de yolluk aldığı tespit edildi”, Akşam gazetesinde 27 Eylül 1960'da "Bayar kahve ithali işinde de ortakmış" gibi haberler buna örnek gösterilebilir.

Bu haber örneklerinde, kamusal senaryolardan normalleştirme söylemi, gündemi yönlendirme söylemi, siyasal konuların kitle iletişim araçları tarafından sınırlandırılması ile siyasetin alt yapısını oluşturmasını içeren siyasetsizleştirme söylemi, bilginin kontrolü ile rızanın oluşturulmasını hedefleyen bilgisizleștirme söylemi, basın aracılığıyla insanların sızlanmadan öteye geçmeyen bireyler haline getirilmesini öngören sivil itaatsizliği kırma söyleminin kullanıldığı görülmektedir.

Ayrıca söz konusu haberler, bilginin çarpık olarak iletilmesi ile yapılan manipülasyonun da bir örneğini oluşturmaktadır. Chomsky’nin medya manipülasyonunun on stratejisi arasında yer alan, dikkat dağıtma (siyasal değişim, yani hükümet darbesinden dikkatin dağıtılması), sorun yarat, çözüm sun (Bir sorun çıkarılması, tepki oluşturulması ve çözüm olarak darbenin sunulması), erteleme (kabul edilemeyecek bir kararı sancılı ve gerekli olarak sunma), toplumu cahil ve sıradan tutma, kendini suçlamayı güçlendirme (kişilerin talihsizliği, zekâsı, yetenek ve çabaları yönünden başarısızlı̆̆ için kendini suçlamasına yol açılması) stratejilerinin kullanıldığı görülmektedir. 27 Mayıs’ın ardından yapılan Yassıada Duruşmaları’nın gerekçeli kararı yıllar sonra açıklanmış, açıklandığında ise özellikle uluslararası medyada yer alan haberlerin Adnan Menderes ve iki bakanın idamı kararında delil olarak sunulması, darbenin meşrulaştırılmasında basının nasıl bir rol oynayabileceğini ortaya koymaktadır.

15 Temmuz 2016'da gerçekleşen Darbe Girişimi öncesinde de, benzer şekilde kamusal senaryolar ve manipülasyon stratejilerinin gazetelerde uygulandı̆̆1 görülmektedir. Bu süreç, "Gezi Olayları", “17-25 Aralık Yolsuzluk İddiaları” ve “Ağustos 2014 Cumhurbaşkanlığı seçimleri öncesi” dönemlerde yapılan gazete haberleri ile irdelenmiştir. 27 Mayıs 2016'da başlayan Gezi olayları, AK Parti iktidarının ve Erdoğan yönetiminin karşı karşıya kaldığı ilk büyük toplumsal eylem olma niteliği taşımaktadır. Gazetelerin bu olayları yansıtma biçimi incelendiğinde, 27 Mayıs’a giden süreçte yaşanan olayların verilme biçimiyle örtüşen bir yaklaşım izlendiği görülmektedir.

Gezi olaylarına ilişkin gerek Cumhuriyet gazetesinde gerekse uluslararası medyada yer alan haberler, Erdoğan yönetimine ilişkin doğrudan, şiddeti teşvik eden, baskıcı, otoriter bir yönetim olduğu söylemi yapılandırılmaya, "Erdoğan’n diktatör olduğu" söyleminin güçlendirilmeye çalışıldığını göstermektedir. Hürriyet gazetesinin, Gezi olaylarına ilişkin haberlerinde, "okumuş genç çocuklara" karşı, güvenlik güçlerinin orantısız şiddet uyguladığı mesajı işlenirken, Erdoğan yönetimi, doğrudan olmasa da dolaylı yoldan "baskıcı bir yönetim” olarak nitelendirilmektedir. Milliyet gazetesinin de, Gezi olaylarını okuyucularına yansıtırken, hükümetin şiddet, otoriterlik, diktatörlük, özgürlükleri kısıtlayan bir yönetim olduğuna ilişkin söyleme fotoğrafları ve haberleri ile katıldı̆̆ görülmektedir.

Türkiye Mart 2014 yerel seçimlerine giderken, Erdoğan’a yöneltilen "diktatörlük”, "otoriterlik” eleştirilerine, 17-25 Aralık 2013'te sonradan FETÖ mensubu oldukları ortaya çıkan bazı polis ve savcıların, Erdoğan’ın yakın çevresine ve bakanlara yönelik başlattıkları operasyonlara ve özellikle sosyal medya kanalıyla yayılan ses kayıtlarına dayandırılan yolsuzluk suçlamaları da eklenmiştir. Gazeteler, Başbakan Erdoğan’n “17-25 Aralık yargı ve polis darbesi” söylemine karşın, düzenli ve tekrar eden bir şekilde olayı "yolsuzluk ve rüşvet operasyonu” ifadesiyle tanımlamaktadır. Bu 
tanımın, haberlerde kırmızı renkle belirginleştirilmesi, üst başlıklarda ve spotlarda vurgulanması yoluyla, "yolsuzluk ve rüşvet" iddiasının üretilmeye ve pekiştirilmeye, kamuoyunun da ikna edilmeye çalışıldığı söylenebilir. Cumhuriyet gazetesinin, 17-25 Aralık operasyonlarını haberleştirirken, yolsuzluk ve rüşvet ile birlikte yargının baskı altına alındığı temasını sistematik bir şekilde aktararak, kamuoyunu yönlendirmeye çalıştığı görülmektedir.

10 Ağustos 2014’te gerçekleşen ve ülke tarihinde ilk kez halkoyu ile gerçekleşen cumhurbaşkanlı̆̆ 1 seçimleri öncesinde de tarama konusu olan ulusal gazetelerde yer alan haberlerde, Erdoğan yönetimine ilişkin yolsuzluk, diktatörlük, otoriterlik söylemini destekleyecek, kamuoyunu ikna edecek başlıkların ve içeriklerin yer aldığı tespit edilmiştir. 15 Temmuz’a giden süreçte, üç dönem üzerinden incelenen haber örneklerinde, Türk ve Damlapınar'ın kamusal senaryo modelinde yer alan, normalleştirme ve gündemi yönlendirme söyleminin, siyasal konuların kitle iletişim araçları tarafından sınırlandırılmasını içeren siyasetsizleştirme söyleminin, bilginin kontrolü ile rızanın oluşturulmasını hedefleyen bilgisizleştirme söyleminin kullanıldığı görülmektedir.

$\mathrm{Bu}$ haberlerin, manipülasyonun hem bilginin çarpık olarak iletilmesi hem de iletilen bilginin ulaşılması hedeflenen görüşe veya duruma meşruiyet kazandırarak sürekli olarak tekrarlanması ve dayatılmasından oluşan iki ölçütünün de kullanıldığı tipik örnekler olduğu da söylenebilir. Haberlerde, Chomsky’nin medya manipülasyonunun on stratejisi arasında yer alan, dikkat dağıtma (siyasal değişim, yani hükümet darbesinden dikkatin dağıtılması), sorun yarat, çözüm sun (bir sorun çıkarılması, tepki oluşturulması ve çözüm olarak darbenin sunulması), erteleme (kabul edilemeyecek bir kararı sancilı ve gerekli olarak sunma), toplumu cahil ve siradan tutma, kendini suçlamayı güçlendirme (kişilerin talihsizliği, zekâsı, yetenek ve çabaları yönünden başarısızlığı için kendini suçlamasına yol açılması) stratejilerinin kullanıldığı görülmektedir.

27 Mayıs Askeri Darbesi’nden farklı olarak, 15 Temmuz 2016'da Cumhurbaşkanı Recep Tayyip Erdoğan ve Başbakan Binali Yıldırım’n Darbe Girişimine karşı halkı sokağa çıkmaya ve direnmeye çağıran açılamalarını yayınlayan televizyon kanalları bulunmaktadır. Radyodan darbelerin ilan edildiği bir dönemden, yeni medyanın unsurlarından birisi olan FaceTime’dan halkın darbeye karşı durmaya çağrıldığı bir döneme geçilmiştir.

Gerek 27 Mayıs Darbesine gerekse 15 Temmuz Darbe Girişimi’ne giden süreçte, kitle iletişim araçlarının söylemleri ile ortaya konulan darbeye rıza üretme çabasının, toplumun bir kesiminde razı olma eğilimini doğurduğu, iki sürecin sonuçları da göz önünde bulundurularak söylenebilir. 27 Mayıs darbesi ve 15 Temmuz Darbe Girişimi öncesinde hem geleneksel medya olarak tanımlanan gazeteler hem de özellikle 15 Temmuz öncesinde yeni medya olarak tanımlanan sosyal medya aracilğ̆ıla topluma iletilen söylemler ve mesajlar, yaşanan sosyal gerçekliği 'kamusal senaryo' metodları ile manipüle etmeye yöneliktir. Her iki olayda da halkın darbeye razı edilmesinde 'kamusal senaryo modeli’nin ayakları ve manipülasyon stratejileri önemli bir işlev üstlenmekte, sosyal gerçekliğe bakış açısını biçimlendirmektedir. 15 Temmuz Darbe Girişiminin başarısızlığa uğramasında, AK Parti hükümetine yakın basın organlarının, halkı ve özellikle de AK Parti tabanını harekete geçirerek, darbeye karşı direnmeye yönelten süreç ise kamusal senaryolar ve medya manipülasyon stratejileri çerçevesinde yapılacak bir başka çalışma ile araştırılması gereken bir konudur. 


\section{Kaynakça}

\#5gündetaksim. (2013, 2 Haziran). Hürriyet. Milli Kütüphane Arşivi: Ankara.

1 Mayıs kalesi. (2014, 2 Mayıs). Milliyet. Milli Kütüphane Arşivi: Ankara.

3 Baba gitti. (2013, 26 Aralık). Hürriyet. Milli Kütüphane Arşivi: Ankara.

4 bakana 1 komisyon. (2014, 6 Mayıs). Milliyet. Milli Kütüphane Arşivi: Ankara.

17-25 Erdoğan. (2014, 23 Nisan). Cumhuriyet. Milli Kütüphane Arşivi: Ankara.

A'dan Z’ye vahşet. (2014, 1 Haziran). Cumhuriyet. Milli Kütüphane Arşivi: Ankara.

Adorno, T. (1998). Minima moralia sakatlanmış yaşamdan yansımalar. O. Koçak ve A. Doğukan (Çev.). İstanbul: Metis Yayınları.

Althusser, L. (2017). İdeoloji ve devletin ideolojik aygıtları. 6. Baskı. A. Tümertekin (Çev.). İstanbul: İthaki Yay.

Arkadaşın babası. (2014, 2 Ağustos). Cumhuriyet. Milli Kütüphane Arşivi: Ankara.

Başgil, A. F. (2011). 27 Mayıs İhtilali ve sebepleri. İstanbul: Yağmur Yayınları.

Baudrillard, J. (1998). Kötülüğün şeffaflı̆̆ı aşırı fenomenler üzerine bir deneme. I. Ergüden (Çev.). İstanbul: Ayrıntı Yayınları.

Baudrillard, J. (1999). Siyah 'an'lar I-II. A. Sönmezay (Çev.). İstanbul: Ayrıntı Yayınları.

Bauman, Z. (1998). Postmodern etik. A. Türker (Çev.). İstanbul: Ayrıntı Yayınları.

Bayar kahve ithali işinde de ortakmış. (1960b, 27 Eylül). Akşam. Milli Kütüphane Arşivi: Ankara

Benhabib, S. (2013, 3 Haziran). Turkey's authoritarian turn. The New York Times. 20 Temmuz 2017 tarihinde http://www.nytimes.com/2013/06/04/opinion/turkeys-authoritarian-turn.html adresinden edinilmiştir.

Bugün bayram, gazdan kaçın çocuklar. (2014, 2 Mayıs). Hürriyet. Milli Kütüphane Arşivi: Ankara.

Burke, P. (2008). Kültür tarihi. 2. Baskı. M. Tunçay (Çev.). İstanbul: İstanbul Bilgi Üniversitesi Yayınları.

Bülbül, R. (2001). Haberin anatomisi ve temel yaklaşımlar. Ankara: Nobel Yayın Dağıtım, 103.

Canclini, N. G. (1999). Kültür ve iktidar araştırmalarının durumu. N. Güngör (Ed.) Popüler kültür ve iktidar içinde, (Çev. S. Öztürk). Ankara: Vadi Yayınları.

Ceylan, C. (2013). Hegemonya, 'hegemonia' olunca”. İstanbul Ticaret Üniversitesi Sosyal Bilimleri Dergisi, 2013, 12(23)s.329-345.

Christie-Miller, A. (2013, 26 Aralık). Call for Erdoğan to quit as he is engulfed in corruption scandal. The Times. 20 Ağustos 2017 tarihinde https://www.thetimes.co.uk/article/call-for-erdogan-to-quit-as-he-isengulfed-in-corruption-scandal-7 $\mathrm{m}$ adresinden edinilmiştir.

Christie-Miller, A. (2014, 31 Temmuz ). Turks fear skewed race will anoint Erdogan as dictator. The Times.17 Haziran 2017 tarihinde https://www.thetimes.co.uk/article/turks-fear-skewed-race-will-anointerdogan-7ztwz657q9p adresinden edinilmiştir.

Chomsky, N. (1995). Medya denetimi immediast bildirgesi. Ş. Süer (Çev.). İstanbul: Tümzamanlar Yayıncllık

Chomsky, N. (2011). 10 strategies of manipulation by the media. 20.03.2018 tarihinde https://parisis.files. wordpress.com/2011/01/noam-chomsky.pdf adresinden edinilmiştir.

Chomsky, N. ve Herman, E. S. (2012). Rızanın imalatı. E. Abadoğlu (Çev.). İstanbul: BGST

Curran, J. (2002). Medya ve demokrasi: Yeniden değer biçme. S. İrvan (Der.). Medya Kültür Siyaset içinde ss. 181-262. Ankara: Alp Yayınevi.

Çaylak, A. (2014). Gülenizm = "Dinci" Kemalizm ya da "Gülen" Kemalizm. Ankara: Murat Kitabevi.

Çaylak, A. ve Dinç, G. (2017). Gülenism as “Religionist” Kemalism. Insight Turkey, 19(3), 181-206.

Çaylak, A. (2018). 15 Temmuz Darbe Girişimi ve Gülenizm’in soykütüğü. A. Çaylak ve S. A. Avcu (Ed.). Türkiye’nin siyasal hayatı içinde, ss.767-779. Ankara: Savaş Yayınları. 
Çırpındıkça batıyor. (2014, 10 Ocak). Cumhuriyet. Milli Kütüphane Arşivi: Ankara.

Damlapınar, Z. (2002). İktidar ve kitle iletişim araçları üzerinden rıza üretimi: Teorik ve ampirik açıdan kamusal senaryo süreci. İletişim Dergisi, 15, 61-89. Ankara: Gazi Üniversitesi.

Demirovic, A. (2007) Toplum ve eleştiri. M. Açıkgöz (Çev.). İstanbul: Felsefelogos Yayınları.

Demirovic, A. (2012). Hegemonya ve iktidar analizi. M. Asa (Çev.). Felsefelogos. 44. 95-104.

Demokrasi için ayağa kalktılar. (2013, 13 Haziran). Cumhuriyet. Milli Kütüphane Arşivi: Ankara.

Doğan, E. (2018). Türkiye'de sol düşünce hareketlerin tarihi. A. Çaylak ve S. A. Avcu (Ed.). Türkiye’nin Siyasal Hayatı içinde, ss.155-169. Ankara: Savaş Yayınları.

Domenach, J-M. (1995). Politika ve propaganda. T. Yücel (Çev.). İstanbul: Varlık Yayınları.

Editorial. (2013, 3 Haziran). Prime Minister Erdogan's strongman response to Turkey's protests. The Washington Post. 7 Ağustos 2017 tarihinde https://www.washingtonpost.com/opinions/prime-minister-erdogansstrongman-response-to-turkeys-protests/2013/06/03/6d83987a-cc78-11e2-8f6b-67f40e176f03_story. html?utm_term $=.14 \mathrm{a} 266 \mathrm{~d} 2894 \mathrm{a}$ adresinden edinilmiştir.

Erdoğan, İ. ve Alemdar, K. (2010). Öteki kuram, kitle iletişim kuram ve araştırmalarının tarihsel ve eleştirel bir değerlendirmesi. (3. Baskı). Ankara: Erk Yayınları.

Fairclough, N. (2015). Dil ve ideoloji. 2. Baskı. B. Çoban vd. (Çev.). B. Çoban (Ed.). Söylem ve İdeoloji içinde ss. 121-135. İstanbul: Su Yayınları.

Farkında mısınız? (2014, 21 Şubat). Cumhuriyet. Milli Kütüphane Arşivi: Ankara

Fisk, R. (2014, Nisan 11). Has Recep Tayyip Erdogan gone from model 'strongman' to tin-pot dictator? The Independent. 15 Ağustos 2017 tarihinde https://turkishpoliticsupdates.wordpress.com/2014/04/14/ robert-fisk-has-recep-tayyip-erdogan-gone-from-mod adresinden edinilmiştir.

Fromm, E. (1995). Umut devrimi insancıllaşmış bir teknolojiye doğru. Ş. Yeğin (Çev.). İstanbul: Payel Yayınları.

Gazi Parkı. (2013, 1 Haziran). Hürriyet. Milli Kütüphane Arşivi: Ankara.

Gezi'de yıkma timi. (2013, 31 Mayıs). Hürriyet. Milli Kütüphane Arşivi: Ankara.

Gramsci, A. (1967). Aydinlar ve toplum. İstanbul: Çan.

Gramsci, A. (2014) Hapishane defterleri. 7. Baskı, A. Çemgil (Çev.). İstanbul: Belge Yayınları.

Halk baskıya ve zulme direniyor. (2013, 17 Haziran). Cumhuriyet. Milli Kütüphane Arşivi: Ankara.

Halk başkaldırdı. (2013, 1 Haziran). Cumhuriyet. Milli Kütüphane Arşivi: Ankara.

Halk direniyor. (2013, 31 Mayıs). Cumhuriyet. Milli Kütüphane Arşivi: Ankara.

Halkla çatışıyor. (2013, 3 Haziran). Cumhuriyet. Milli Kütüphane Arşivi: Ankara.

Hall, S. (1994). İdeolojinin yeniden keşfi: Medya çalışmalarında baskı altında tutulanın geri dönüşü. M. Küçük (Çev.). M. Küçük (Ed.). Medya, iktidar, ideoloji içinde ss. 57-103. Ankara: Ark Yayınları.

Herman, E.S. ve Chomsky, N. (1988). Manufacturing consent: The political economy of the mass media. London: Vintage.

İnönü: Biz, bir ihtilâl ve inkılâp rejiminden geldik. (1958, 19 Ekim). Ulus. Milli Kütüphane Arşivi: Ankara İnönü’nün Ege gezisi dün hadiseli başladı. (1959, 30 Nisan). Cumhuriyet. Milli Kütüphane Arşivi: Ankara K. Aygün, belediye tahvillerini kırdırıp kendi hesabına toplamış. Bekçi aidatlarının da yenildiği anlaşılıyor. (1960a, 12 Temmuz). Akşam. Milli Kütüphane Arşivi: Ankara.

Kaya, R. ve Çakmur, B. (2012). Siyaset bilimi ve medya çalışmaları. G. Atılgan ve E. A. Aytekin (Ed.). Siyaset bilimi kavramlar ideolojiler disiplinler arası ilişkiler içinde ss. 517-528. İstanbul: Yordam Kitap.

Keane, J. (1999). Medya ve demokrasi. H. Şahin (Çev.). İstanbul: Ayrıntı Yayınları.

Kürsüde inkâr. (2014, 6 Mayıs). Hürriyet. Milli Kütüphane Arşivi: Ankara. 
Marcuse, H. (1968). Tek boyutlu insan ileri endüstriyel toplumun ideolojisi üzerinde inceleme. S. Çağan (Çev.). İstanbul: Haşmet Yayınları.

Marshall, G. (1999). Sosyoloji sözlüğü. O. Akınhay ve D. Kömürcü (Çev.). Ankara: Bilim ve Sanat Yayınları.

Megill, A. (1998). Aşırılı̆̆ın peygamberleri Nietzche, Heidegger, Foucault, Derrida. T. Birkan (Çev.). Ankara: Bilim ve Sanat Yayınları.

Menderes: Anarşist hareketlere paydos diyeceğiz. (1958, 20 Ekim). Akşam. Milli Kütüphane Arşivi: Ankara

Menderes dün yeşil bayrakla karşılandı. (1958, 20 Ekim). Vatan. Milli Kütüphane Arşivi: Ankara

Menderes 10 yılda 480 bin lira maaş ve tazminat almış. Sabık Başbakanın 1954 ve 1957 seçimlerinde yaptığ propaganda gezileri için de yolluk aldığı tespit edildi. (1960b, 13 Temmuz). Milliyet. Milli Kütüphane Arşivi: Ankara.

Miller, D., Coleman, J.,Connolly W., Ryan, A. (1994). Blackwell’in siyasal düşünceler ansiklopedisi A-J’. Çev. B. Paker ve N. Kıraç (Çev.). Ankara: Ümit Yayıncılık.

Mulgan, G. (1995). Antipolitik çağda politika. A. Yılmaz (Çev.). İstanbul: Ayrıntı Yayınları.

Mutsuzluğun resmini çizdik. (2013, 29 Mayıs). Milliyet. Milli Kütüphane Arşivi: Ankara.

Ne bu şiddet bu celal. (2013, 1 Haziran). Milliyet. Milli Kütüphane Arşivi: Ankara

Noelle-Neumann, E. (1998). Kamuoyu suskunluk sarmalının keşfi. M. Özkök (Çev.). Ankara: Dost Yayınları.

Paralar saçıldı. (2013, 19 Aralık). Milliyet. Milli Kütüphane Arşivi: Ankara.

Parayı vekilin oğlu getirdi. (2013, 23 Aralık). Hürriyet. Milli Kütüphane Arşivi: Ankara

Pimi çektiler. (2013, 18 Aralık). Cumhuriyet. Milli Kütüphane Arşivi: Ankara.

Portelli, H. (1982). Gramsci ve tarihsel blok. K. Somer (Çev.). Ankara: Savaş Yayınları.

Rezalet diz boyu. (2013, 19 Aralık). Cumhuriyet. Milli Kütüphane Arşivi: Ankara.

Rigel, N. (2000). Rüya körleşmesi. İstanbul: Der Yayınları.

Russell, B. (1990). İktidar. M. Ergin (Çev.). İstanbul: Cem Yayın Evi.

Sabık Cumhurbaşkanı 1500 Harbiyelinin imhasında hiç mahzur olmadığını söylemiş. (1960a, 13 Temmuz). Milliyet. Milli Kütüphane Arşivi: Ankara.

Savcıdaki fotoğraflar. (2013, 19 Aralık). Hürriyet. Milli Kütüphane Arşivi: Ankara.

Schiller, H. (1993). Zihin yönlendirenler. C. Cerit (Çev.). İstanbul: Pınar Yayınları.

Sholle, D. (1994). Eleştirel çalışmalar: İdeoloji teorisinden iktidar/bilgiye. Medya, İktidar, İdeoloji içinde, (Çev. M. Küçük). Ankara: Ark Yayınları.

Son durağa doğru. (2013, 29 Mayıs). Cumhuriyet. Milli Kütüphane Arşivi: Ankara.

Sosyal gözaltı. (2013, 6 Haziran). Hürriyet. Milli Kütüphane Arşivi: Ankara.

Stevenson, N. (2008). Medya kültürleri sosyal teori ve kitle iletişimi. G. Orhon ve B. E. Aksoy (Çev.). Ankara: Ütopya Yayınevi.

Subramanian, C. (2013, 26 Aralık ). Turkish leader lashes out at corruption probe. Time. 10 Temmuz 2017 tarihinde http://world.time.com/2013/12/26/turkish-leader-lashes-out-at-corruption-probe/ adresinden edinilmiştir.

Şok operasyon.(2013, 18 Aralık). Milliyet. Milli Kütüphane Arşivi: Ankara.

Tek adam mı demokrasi mi? (2014, 9 Ağustos). Cumhuriyet. Milli Kütüphane Arşivi: Ankara

Thomas, P. (2013). Gramsci'de diyalektik hegemonya. R. Caner (Çev.). Felsefelogos, 48, 11-17.

Tokgöz, O. (1979). Siyasal haberleşme ve kadın. Ankara: A.Ü. SBF. 
Tucker, J. (2013, 26 Aralık). Talking Turkey: How does corruption affect voting behavior? The Washington Post. 20 Ağustos 2017 tarihinde https://www.washingtonpost.com/news/monkey-cage/wp/2013/12/26/ talking-turkey-how-does-corruption-affect-vo adresinden edinilmiştir.

Türk, M. S. (2017). Medya halkı nasıl razı eder? Ictmedia, Kasım, 18-20, Ankara.

Uşakta dün müessif hâdiseler oldu. (1959, 1 Mayıs). Cumhuriyet. Milli Kütüphane Arşivi: Ankara

Uzun, R. (2011). İletişim etiği sorunlar sorumluluklar. Ankara: Dipnot Yayınları

Watson, I., ve Levs, J. (2013, 4 Haziran). Turkey’s Erdogan: Successful leader or 'dictator'? CNN. 7 Ağustos 2017 tarihinde http://edition.cnn.com/2013/06/04/world/europe/turkey-erdogan/index.html adresinden edinilmiştir.

Yassıada Broşürü. (Ekim-1960). İstanbul: T.C Milli Birlik Komitesi İrtibat Bürosu, 1960. http://menadoc. bibliothek.uni-halle.de/landau/content/titleinfo/208980 Erişim Tarihi: 20.08.2017

Yaylagül, L. (2010). Kitle iletişim kuramları egemen ve eleştirel yaklaşımlar. Ankara: Dipnot Yayınları.

Yazık. (2013, 12 Haziran). Hürriyet. Milli Kütüphane Arşivi: Ankara.

Yerdeş, G. (2006). Başkentte önemli olaylar ve yazamadıklarım. Ankara: Ümit Yayıncılık.

Yolsuzlukları ispatlayacağız. (2014, 13 Nisan). Cumhuriyet. Milli Kütüphane Arşivi: Ankara

Yüksek Adalet Divanı Gerekçeli Kararları. (1960-1961). Adnan Menderes’in Avukatı Burhan Apaydın’n Arşivi: İstanbul.

Zeldin, T. (1998). İnsanlı̆̆ın mahrem tarihi. E. Özsayar (Çev.). İstanbul: Ayrıntı Yayınları.

Zile’de dün müessif hadiseler oldu. (1958, 18 Ekim). Cumhuriyet. Milli Kütüphane Arşivi: Ankara

Zile’de İnönüyü karşılayan yurttaşlar bomba ve silahlarla dağıtılmak istendi. (1958, 18 Ekim). Ulus. Milli Kütüphane Arşivi: Ankara.

Zorlu, Y. (2016). Uluslararası iletişim düzeni ve batı egemenliği. Uluslararası Sosyal Araştırmalar Dergisi, 9 (42), 845-857 